\title{
EARNING EXCLUSIVITY: GENERIC DRUG INCENTIVES AND THE HATCH-WAXMAN ACT
}

\author{
C. Scott Hemphill \\ MARK A. LeMLeY*
}

A quarter century ago, Congress fundamentally changed the way the Food and Drug Administration approves pharmaceuticals for the market. The Hatch-Waxman Act gave additional protection to the inventors of new drugs, both by lengthening patent terms and by providing guaranteed periods of data exclusivity. ${ }^{1}$ In exchange, Hatch-Waxman made it easier for generic drug manufacturers to enter the market with a copy of the drug, either by waiting until the patent expires or by challenging weak patents. To encourage generic manufacturers to identify and challenge weak patents, Hatch-Waxman offered a sort of quasi-exclusive right to the generic challenger. The first generic manufacturer to file for approval with the FDA, with caveats discussed below, is entitled to 180 days of "generic exclusivity" when it first enters the market. During that period, other generic drug makers are prohibited from entering the market. The point was to offer a carrot, encouraging generic firms to challenge and invalidate bad patents (or invent around them) early and often, and accordingly get generic drugs on the market earlier. ${ }^{2}$

* The authors are, respectively, Professor of Law, Columbia Law School; and William H. Neukom Professor, Stanford Law School. We thank Mike Carrier, Tom Cotter, Einer Elhauge, Al Engelberg, Robin Feldman, Rose Hagan, Michael Kades, Elizabeth Leff, Christopher Leslie, Andreas Reindl, Steve Shadowen, Danny Sokol, Shashank Upadhye, and audiences at Brooklyn, Loyola of Los Angeles, and the annual conferences of the Association of American Law Schools and the American Law and Economics Association, for helpful discussion and comments. Taylor Kirklin, Annie Liang, Tejas Narechania, and Lenny Traps provided outstanding research assistance. Professor Hemphill has served as a consultant to the FTC on antitrust issues in the pharmaceutical industry, and Professor Lemley represented Impax, an antitrust plaintiff in Abbott Labs. v. Impax Labs., a case discussed infra.

${ }^{1}$ Drug Price Competition and Patent Term Restoration Act of 1984, Pub. L. No. 98-417, 98 Stat. 1585 (1984) (codified as amended in scattered sections of 15, 21, 35, and 42 U.S.C.). In 2003, Congress amended this scheme in Title XI of the Medicare Prescription Drug, Improvement, and Modernization Act of 2003, Pub. L. No. 108-173, tit. XI, subtits. A-B, 117 Stat. 2066, 2448-64 (codified at 21 U.S.C. § 355 (2006)).

${ }^{2}$ See, e.g., FDA, Effective Date of Approval of an Abbreviated New Drug Application, 63 Fed. Reg. 59,710, 59,711 (Nov. 5, 1998) (180-day period "created as an incentive to generic

77 Antitrust Law Journal No. 3 (2011). Copyright 2011 American Bar Association. Reproduced by permission. All rights reserved. This information or any portion thereof may not be copied or disseminated in any form or by any means or downloaded or stored in an electronic database or retrieval system without the express written consent of the American Bar Association. 
It isn't working. Pharmaceutical patent owners have responded to HatchWaxman with a sophisticated program of "product lifecycle management," which is code for finding ways to extend exclusivity as long as possible. They have filed multiple patents on variants of the same drug, listed patents with the FDA that don't cover the product, taken advantage of litigation rules to stay generic entry, and "product-hopped" (made small changes to a product timed to prevent generic entry). Most of all, they have paid their potential generic competitors to abandon their challenges, keeping weak patents intact and preventing competition.

Prior scholarship has focused on exclusion payments and lifecycle management as efforts driven by the patent owner. In fact, however, it is not just patent owners but generic pharmaceutical companies that have incentives to game the Hatch-Waxman Act. "Reverse" or "exclusion" payments to settle pharmaceutical patent lawsuits are facilitated because the Hatch-Waxman Act has been interpreted to give 180 days of generic exclusivity to the first generic company to file for FDA approval, whether or not that company succeeds in invalidating the patent or finding a way to avoid infringement. As a result, the patentee can "buy off" the first generic entrant, paying it to delay entry into the market. Meanwhile, the generic firm retains the valuable period of exclusivity. ${ }^{3}$ If that first generic is entitled to its 180 days, no one else can enter until after the exclusivity period has expired or been forfeited. ${ }^{4}$ Moreover, the

manufacturers to challenge patents that may be invalid, not infringed, or unenforceable"); Caraco Pharm. Labs., Ltd. v. Forest Labs., Ltd., 527 F.3d 1278, 1283 (Fed. Cir. 2008) (point of 180-day period is "to incentivize ANDA filers to challenge the validity of listed patents or design around those patents as early as possible"); Teva Pharm. Indus. v. Crawford, 410 F.3d 51, 53-54 (D.C. Cir. 2005) (noting that Congress "clearly" "intended to create an incentive to challenge branddrug patents" by means of the 180-day period); Sandoz, Inc. v. FDA, 439 F. Supp. 2d 26, 29, 33-34 (D.D.C. 2006) ("Congress . . . provid[ed] first-filers with a 180-day exclusivity period in order to reward their risk-taking and encourage further patent challenges in the future."); S. REP. No. 107-167, at 4 (2002) (generic drug makers "are encouraged to challenge weak or invalid patents . . . so consumers can enjoy lower drug prices" by means of the 180-day period); 149 Cong. Rec. S16,104 (daily ed. Dec. 9, 2003) (statement of Sen. Orrin Hatch) ("The 180-day marketing exclusivity rules were first enacted as part of the Waxman-Hatch Act. The policy behind these provisions is to benefit the public by creating an atmosphere that ensures vigorous challenges of the patents held by innovator drug firms."); 149 CoNG. REC. S15,882, S15,884 (daily ed. Nov. 25, 2003) (statement of Sen. Ted Kennedy) (180-day period "encourages generic companies to challenge patents that are likely invalid or not infringed and, because it goes to the first generic applicant to challenge a brand-name drug patent, it encourages challenges of those patents as soon as possible").

${ }^{3}$ Generics often make more than half of their total profits on a drug during the period of generic exclusivity. "In general, most generic drug companies estimate that $60 \%$ to $80 \%$ of their potential profit for any one product is made during this exclusivity period." Daniel F. Coughlin \& Rochelle A. Dede, Hatch-Waxman Game-Playing from a Generic Manufacturer Perspective, 25 Biotech. L. Rep. 525, 525-26 (2006). See also Martin A. Voet, The Generic Challenge: Understanding Patents, FdA and Pharmaceutical Life-Cycle Management 61 (2005) (stating that the 180-day period often provides the majority of total profits).

${ }^{4}$ This description applies to drugs with "new ANDAs"- that is, drugs whose first ANDA with a Paragraph IV certification was filed after December 8, 2003. (Paragraph IV certifications, 
chance to lock in the benefits of exclusivity, rather than risking its loss in patent litigation, encourages the generic firm to enter into settlements that are bad for consumers.

The result is that the 180-day exclusivity period is not serving its purpose of eliminating weak patents. True, it is encouraging lots of challenges to those patents. But it is also encouraging the challengers to accept compensation to drop those challenges, rather than taking them to judgment and benefiting the rest of society.

To be sure, many of these "lifecycle management" strategies have been challenged as violations of antitrust law. The results have been mixed. As we explain below, antitrust challenges have arguably succeeded in curbing certain types of behavior, but have been less successful, at least thus far, in curbing anticompetitive settlements. Meanwhile, a large literature has accumulated that considers the appropriate treatment of various tactics under existing antitrust law or else evaluates the merits of new antitrust prohibitions to fill in the gaps. $^{5}$

Our approach is different. We focus on the other side of the coin-the way a generic's incentives contribute to the anticompetitive misuse of Hatch-Waxman. We propose to resolve competition concerns related to anticompetitive effects of settlements by focusing on the Hatch-Waxman statutory scheme itself. Under our proposal, the first generic would be entitled to the 180-day exclusivity period only if it successfully defeats the patent owner (for example, by invalidating the patent or by proving that it did not infringe that patent), obtains a settlement that permits entry without delay, or can enter the market without delay because the patent holder does not sue for infringement. After all, the point of 180-day exclusivity was to encourage challenges to patents because the invalidation of bad patents benefits society as a whole. ${ }^{6}$ Society doesn't benefit from a private deal to drop a challenge that has the effect of limiting competition. That doesn't mean settlement is never a good idea; it is a commonplace in our legal system. But it seems bizarre to insulate a company from competition just because it settles the case. Indeed, we expect

and other technical details of the Hatch-Waxman procedure, are explained infra.) For old ANDAs, the relevant event is the triggering of the first filer's exclusivity, rather than forfeiture.

${ }^{5}$ See, e.g., sources cited infra notes $54 \& 61$.

${ }^{6}$ See, e.g., Lear, Inc. v. Adkins, 395 U.S. 653, 670 (1969) (emphasizing the "public interest in permitting full and free competition in the use of ideas," and holding that a licensee was not estopped from attacking patent validity); Wembley, Inc. v. Superba Cravats, Inc., 315 F.2d 87, 89 (2d Cir. 1963) (quoting Hand, J., Bresnick v. U.S. Vitamin Corp., 139 F.2d 239, 242 (2d Cir. 1943)) (noting the potential "scarecrow" effect of an invalid patent, even where not litigated, on potential entrants); Christopher R. Leslie, The Anticompetitive Effects of Unenforced Invalid Patents, 91 MinN. L. REv. 101, 113-39 (2006) (analyzing the mechanism and consequences of this scarecrow effect). 
that our proposal, if implemented, would facilitate more rational settlements that accurately reflect the likelihood of success in litigation.

We believe that our proposal could be implemented without any legislative action, for example, by the FDA in interpreting the Hatch-Waxman Act. The FDA took a similar view in the 1990s, under different statutory language, but the D.C. Circuit held that the statute did not support it. ${ }^{7}$ It also could be implemented by the Federal Trade Commission using its enforcement powers under Section 5 of the FTC Act. Alternatively, we propose a simple change to the statute that would have the desired effect of limiting 180-day exclusivity to those who have earned it. Doing so will not solve every threat to competition in the pharmaceutical industry, but it will make a significant start.

To be clear, we do not oppose settlements that simply divide the remaining patent term by choosing a date at which the generic firm may enter. ${ }^{8}$ The problem arises when, in addition to dividing the term, the generic firm retains eligibility for the exclusivity period. Courts are in broad agreement that retained exclusivity is troubling even as they disagree about the antitrust treatment of cash payments in exchange for delayed entry. ${ }^{9}$ Even those who think cash payments for delay pose no antitrust problem should be concerned about the bad consequences of retained exclusivity. Moreover, existing critiques and defenses of settlement tend to ignore the specific legal impediments and economic disincentives to early generic entry that are created by retained exclusivity. ${ }^{10}$

We provide the background of the Hatch-Waxman Act in Part I. In Part II, we discuss the ways patent owners have circumvented the purpose of the statute, the various efforts-principally as a matter of antitrust-that courts, agencies, and Congress have made to close those loopholes, and why they haven't solved the problem. Part III sets out our basic proposal. Part IV considers the effects of requiring generic challengers to earn their exclusivity and

\footnotetext{
${ }^{7}$ As explained infra, our approach is more generous than the FDA's successful defense requirement in significant respects. For example, we would grant exclusivity where a first-filing generic firm is never sued and therefore permitted to enter the market immediately.

${ }^{8}$ See, e.g., C. Scott Hemphill, Collusive and Exclusive Settlements of Intellectual Property Litigation, 2010 Colum. Bus. L. Rev. 685, 703 (endorsing term-division settlements as properly reflecting the inherent strength of the patent); Herbert Hovenkamp et al., Anticompetitive Settlement of Intellectual Property Disputes, 87 Minn. L. Rev. 1719, 1762 (2003) (same).

${ }^{9}$ See, e.g., In re Ciprofloxacin Hydrochloride Antitrust Litig., 544 F.3d 1323, 1336 (Fed. Cir. 2008); In re Tamoxifen Citrate Antitrust Litig., 466 F.3d 187, 215 (2d Cir. 2006); Valley Drug Co. v. Geneva Pharms., 344 F.3d 1295, 1306 n.18 (11th Cir. 2003); In re Cardizem CD Antitrust Litig., 332 F.3d 896, 907-08 (6th Cir. 2003); King Drug Co. of Florence, Inc. v. Cephalon, Inc., 702 F. Supp. 2d 514, 534, 535-36 (E.D. Pa. 2010). Indeed, even pharmaceutical companies defending the legality of exclusion payments have pointed to the retained exclusivity aspect of Cardizem as a reason to distinguish it from other kinds of pay-for-delay cases.

${ }^{10}$ Some early pay-for-delay settlements arose while the FDA gave exclusivity only to those who successfully defended a suit. In those cases, retained 180-day exclusivity was not an issue.
} 
some possible objections to the proposal. Part V examines how earned exclusivity compares to other suggested changes to the statutory scheme.

\section{THE HATCH-WAXMAN ACT AND GENERIC CHALLENGES}

\section{A. Paragraph IV Challenges}

Generic drug challenges target brand-name drugs that are already on the market. Under federal law, a brand-name firm must demonstrate that a new drug is safe and effective before the FDA will approve it for marketing. Making that demonstration as part of a so-called New Drug Application (NDA) is a lengthy, expensive process, consuming years and many millions of dollars to conduct the necessary clinical trials. ${ }^{11}$

Once the brand-name firm places a new drug on the market, a generic firm may seek to market a competing, "therapeutically equivalent" version of the same drug by filing an Abbreviated New Drug Application, or ANDA, with the FDA. The generic firm must demonstrate that its proposed drug is "bioequivalent" to the brand-name drug - that it uses the same active ingredient, and will be absorbed by the body at the same rate and to the same extent as the brand-name drug. ${ }^{12}$ New clinical trials, however, are not required. An ANDA costs around $\$ 1$ million to prepare. ${ }^{13}$

Most new drugs are protected by one or more patents. Those patents are listed by the brand-name firm in an FDA document commonly known as the

\footnotetext{
${ }^{11}$ Joseph A. DiMasi et al., The Price of Innovation: New Estimates of Drug Development Costs, 22 J. Health Econ. 151 (2003) (estimating that the costs of clinical tests constitute more than half the total cost of drug development). See id. at 162 tbl.1, 165 (estimating out-of-pocket costs of $\$ 130$ million per successful drug, which rises to $\$ 467$ million if an estimate of the cost of failure is attributed to the successes and applying an 11 percent discount rate to the later outlays); $i d$. at 166 (separately estimating out-of-pocket and capitalized preclinical costs to be $\$ 121$ million and \$355 million respectively). Other cost estimates for the entire drug discovery and development process range from $\$ 110$ million to $\$ 500$ million; the latter is an industry figure. Compare Prescription Drug Coverage, Hearing Before the S. Comm. on Fin., 106th Cong., 2000 WL 310076 (Mar. 22, 2000) (testimony of Alan F. Holmer, President and Chief Executive Office, Pharm. Research \& Mfrs. of America Comm. on Fin.) ("On average, it takes 12 to 15 years and \$500 million to develop a new drug and bring it to market.”), with Pub. Citizen, Rebuttals to PhRMA Responses to the Public Citizen Report, "Rx R\&D Myths: The Case Against the Drug Industry's 'Scare Card,"” http://www.citizen.org/congress/reform/drug_industry/corporate/articles.cfm? $\mathrm{ID}=6514$ (criticizing industry estimates and offering the lower figure).

1221 U.S.C. $\S 355(\mathrm{j})(8)(\mathrm{B})$. The applicant must also demonstrate that the generic drug contains the same conditions of use, route of administration, dosage form, strength, and labeling. $\S 355(\mathrm{j})(2)(\mathrm{A})$.

${ }^{13}$ See Requirements for Submission of In Vivo Bioequivalence Data; Proposed Rule, 68 Fed. Reg. 61,640,61,645 (Oct. 29, 2003) (reporting estimates of ANDA preparation and filing costs between $\$ 300,000$ and $\$ 1$ million).
} 
Orange Book. ${ }^{14}$ The generic firm, faced with this array of patents, may choose not to challenge any patents, in which case the FDA delays ANDA approval until expiration of the last listed patent.

In many cases, however, the generic firm attempts to enter prior to the expiration of the brand-name patents. A generic firm seeking pre-expiration entry files an ANDA containing a "Paragraph IV" certification, asserting that applicable patents are invalid or not infringed by the proposed generic product. ${ }^{15}$ The filing of such an ANDA is an act of patent infringement. ${ }^{16}$ In response to the ANDA, the brand-name firm may file a patent infringement suit to establish validity and infringement. ANDA-based patent litigation has a special feature, an automatic statutory stay that blocks FDA approval of the generic drug while the litigation is pending for up to thirty months. ${ }^{17}$ This pattern-launch, challenge, sue-is frequent for major drugs, and it has become the norm for the top-selling drugs. ${ }^{18}$ Litigation raises the expense of a Paragraph IV challenge to $\$ 10$ million or more. ${ }^{19}$

Once multiple generic firms enter the market, prices fall, often dramatically. Consider the case of simvastatin, a blockbuster treatment for high cholesterol sold under the brand name Zocor. The first generic firm received approval in June 2006. By early 2007, a month's worth of generic simvastatin sold for as little as $\$ 7$, compared to more than $\$ 150$ for Zocor. ${ }^{20}$ As prices fall, quantities may increase too. In the eighteen months after the arrival of generic simvastatin, for example, prescriptions increased by more than 70 percent. ${ }^{21}$

${ }^{14}$ The official name is the Approved Drug Products with Therapeutic Equivalence Evaluations. The Orange Book also lists, for each brand-name drug, any unexpired regulatory exclusivity and approved therapeutically equivalent generic drugs.

1521 U.S.C. $\$ 355(\mathrm{j})(2)(\mathrm{A})(\mathrm{vii})(\mathrm{IV})$. There are three alternative certifications, called Paragraphs I, II, and III. See § 355(j)(2)(A)(vii)(I)-(III). Except where otherwise noted, we limit our attention to ANDAs with Paragraph IV certifications.

1635 U.S.C. $\S 271(\mathrm{e})(2)(\mathrm{A})$.

$17 \S 355(\mathrm{j})(5)(\mathrm{B})(\mathrm{iii})$. The stay takes effect provided that the brand-name firm files suit within forty-five days of receiving notice of the certification. Receipt of notice starts the thirty-month clock, so the maximum duration of the stay is generally slightly less than thirty months. Under certain special circumstances, the stay lasts for more than thirty months.

${ }_{18}$ C. Scott Hemphill \& Bhaven N. Sampat, When Do Generics Challenge Drug Patents?, 8 J. EMPIRICAL Legal Stud. 613 (forthcoming 2011), available at http://ssrn.com/abstract=1640512.

${ }^{19}$ Marc Goodman et al., Quantifying the Impact from Authorized Generics 9 (Morgan Stanley Research Report 2004). Nonetheless, challenging patents frequently pays quite handsomely, either in profits from sales in the market or in the form of reverse payments to stay out of the market.

${ }^{20}$ Sarah Rubenstein, Why Generic Doesn't Always Mean Cheap, Wall St. J., Mar. 13, 2007, at D1 (reporting \$154.99 retail price for thirty tablets of 20-mg dose of Zocor at CVS, compared to $\$ 6.97$ for simvastatin at Sam's Club). The average retail price during this period was higher because some retail outlets charged much more than \$6.97. Id.

${ }^{21}$ Murray Aitken, Ernst R. Berndt \& David M. Cutler, Prescription Drug Spending Trends in the United States: Looking Beyond the Turning Point, 28 Health AfF., w151, w156-w158, exh. 5 (2009) (reporting increase from 2.8 million to 4.8 million annual prescriptions). 


\section{B. The 180-Day Exclusivity Period}

Generic firms have a special incentive to challenge a patent, particularly patents that are likely to be invalid or not infringed. That is due to a second special feature of the Hatch-Waxman regime: The first generic firm to file an ANDA is entitled, upon FDA approval, to a 180-day exclusive right to market its product in competition with the brand-name firm before other generic firms may enter. This exclusivity period provides a bounty to generic firms that incur the costs of Paragraph IV challenges and helps to overcome a collective action problem in challenging patents, since a successful invalidity challenge can be exploited by other generic drug makers. ${ }^{22}$

The bounty is a quasi-exclusive right for generic firms. Like a patent, the exclusivity period is a profitable source of exclusion of competitors. During the 180-day period, only the first generic and the brand-name firm are in the market. ${ }^{23}$ For many drugs, the exclusivity period offers the majority of the profits available to the generic firm, since profits fall sharply once other generic firms enter the market. ${ }^{24}$ In some cases, the falloff in sales can be extreme. ${ }^{25}$ Often, the exclusivity period also provides a head-start in signing up customers that carries over after exclusivity expires and other firms enter. ${ }^{26}$

From a social welfare perspective, there are two effects that may offset the benefits discussed in the text. First, the quantity of other drugs in the same class may fall. For example, in the case of Zocor, the quantity of another cholesterol-lowering drug, Lipitor, fell as simvastatin use increased. Id. Second, brand-name drug makers reduce marketing in response to generic entry, which reduces utilization. See Frank R. Lichtenberg \& Gautier Duflos, The Effect of Patent Expiration on U.S. Drug Prices, Marketing, and Utilization by the Public (Manhattan Inst. for Policy Research, Medical Progress Report No. 11, Oct. 2009), available at http://www.manhattan-institute.org/html/mpr_11.htm; Darius Lakdawalla et al., Intellectual Property and Marketing (Nat'l Bureau of Econ. Research Working Paper No. 12577, 2006). Cf. Gideon Parchomovsky \& Peter Siegelman, Towards an Integrated Theory of Intellectual Property, 88 VA. L. Rev. 1455, 1516-17 (2002) (observing that brand-name drug makers sometimes raise prices upon generic entry, relying on the brand to drive a few sales at the higher price).

${ }^{22}$ Blonder-Tongue Labs., Inc. v. Univ. of Ill. Found., 402 U.S. 313, 349 (1971); Joseph Scott Miller, Building a Better Bounty: Litigation-Stage Rewards for Defeating Patents, 19 BERKELEY TECH. L.J. 667, 687-88 (2004) (recognizing public-good characteristic of patent challenges); Joseph Farrell \& Robert P. Merges, Incentives to Challenge and Defend Patents: Why Litigation Won't Reliably Fix Patent Office Errors and Why Administrative Patent Review Might Help, 19 Berkeley Tech. L.J. 943, 952 (2004) (similar); John R. Thomas, Collusion and Collective Action in the Patent System: A Proposal for Patent Bounties, 2001 U. ILL. L. Rev. 305, 333 (similar). Noninfringement claims are more complicated, because they may be specific to the strategy pursued by a particular generic firm.

${ }^{23}$ As discussed infra, in some cases the brand-name firm also authorizes an additional generic firm, using the brand-name firm's own product approval, as an additional competitor.

${ }^{24}$ See supra note 3.

${ }^{25}$ Gardiner Harris \& Joanna Slater, Bitter Pills: Drug Makers See "Branded Generics" Eating into Profits, Wall ST. J., Apr. 17, 2003, at A1 (reporting that Barr's generic version of Prozac had revenue of $\$ 366$ million during the 180-day period, and $\$ 4$ million in subsequent six months).

${ }^{26}$ VOET, supra note 3, at 61 (noting that generic firm that enjoys exclusivity often maintains a majority of sales even once the other firms enter). 
These profits come at the expense of higher prices for consumers. During the exclusivity period, the price discount from monopoly is slight. The FDA has estimated an average price discount of just 6 percent when there is only one generic manufacturer competing with the brand-name firm. ${ }^{27}$ In the case of Zocor, the difference in retail prices between the brand-name drug and the exclusive generic was about 10 percent. ${ }^{28}$ The entry of additional competitors reduces the price sharply, and the more generic competitors, the lower the price. $^{29}$

The lessons of patent policy apply to the generic firm's quasi-exclusivity. One of these lessons is that legal exclusivity ought to be doled out only where it can be expected to induce desirable behavior. Otherwise, the public will suffer high prices and deadweight loss from exclusion, without any compensating benefit from the induced behavior. In the case of patents, that means granting a patent where the prospect of exclusivity will induce socially valuable R\&D into developing new drugs..$^{30}$ In the case of generic-firm quasi-exclusivity, we would like to design the exclusive right so that it is limited to situations where the generic drug maker is doing something that merits a reward.

In the early years of the Hatch-Waxman Act, the FDA applied this lesson in restricting the availability of the generic exclusivity. In particular, the agency awarded quasi-exclusivity only to generic drug makers that "successfully defended" a patent suit. In other words, to win the bounty, a generic drug maker had to file a Paragraph IV certification, be sued by the brand-name firm, and win the subsequent suit. If the generic drug maker settled the case in a manner that delayed entry, or was never sued, no exclusivity was awarded. During

${ }^{27}$ Food \& Drug Admin., Generic Competition and Drug Prices (Mar. 3, 2010), http://www. fda.gov/AboutFDA/CentersOffices/CDER/ucm129385.htm. The FDA analyzed retail sales data for drugs sold between 1999 and 2004. They found that in markets with a single generic drug maker, the relative price of the generic firm was 94 percent of the brand-name firm.

${ }^{28}$ Shannon Pettypiece \& Justin Blum, Merck's Zocor Gets Additional Generic Competition, Bloomberg News, Dec. 27, 2006 (noting, at the end of the exclusivity period, that 20-milligram Zocor sold for $\$ 4.53$ per pill, compared to $\$ 4.16$ for Teva's generic version).

${ }^{29}$ According to the FDA's calculations, for markets with two generic drug makers the relative price fell to 52 percent, and with five generic drug makers to 33 percent, of the brand price. See supra note 27. The price continued to fall with additional drug makers. See also Ernst R. Berndt et al., Authorized Generic Drugs, Price Competition, and Consumers' Welfare, 26 Health Aff. 790, 792-93, exh.1 (2007) (finding, for a set of drugs experiencing generic entry between 1999 and 2003, that as number of generic firms rises, price falls to 25 percent of brand-name price or less).

${ }^{30}$ For scholarly research questioning whether the current patent and regulatory rules actually encourage the development of new drugs, as opposed to incremental changes in existing drugs, see Ron A. Bouchard et al., The Pas de Deux of Pharmaceutical Regulation and Innovation: Who's Leading Whom?, 24 Berkeley TeCh. L.J. 1461 (2009). 
this period, awards of exclusivity were rare. The FDA awarded the bounty just three times between 1984 and 1998, all of them before 1992.31

In 1998, the courts rejected this limitation on generic exclusivity as an impermissible interpretation of the Act's text, ${ }^{32}$ and the FDA changed its interpretation accordingly. ${ }^{33}$ Since 1998 , a first-to-file generic drug maker has been eligible for the bounty provided that it does not lose the patent suit, even if it never actually wins the patent litigation. Indeed, it may earn the exclusivity even if it was never sued, so long as it was the first to file an ANDA.

Zocor again provides a useful illustration. The generic challenger did not challenge the basic composition of matter patent, but did file Paragraph IV certifications challenging two additional ancillary patents that the brand-name firm had listed on the Orange Book. The brand-name firm declined to sue on those ancillary patents, which expired later than the basic patent. The FDA approved the generic product upon the expiration of the basic patent, and awarded exclusivity thanks to the Paragraph IV certification on the other two patents. ${ }^{34}$ Although the generic firm did not invalidate any patent through litigation, the generic firm enjoyed the bounty. We return to the difficult question of no-litigation awards of exclusivity in the analysis below.

${ }^{31}$ These awards were for generic versions of Maxzide (ANDA \#71-360 of Vitarine, exclusivity expiring in April 1988), Flexeril (ANDA \#71-611, Watson, November 1989), and Procardia (ANDA \#72-409, Chase, March 1991). Exclusivity awards are recorded in old versions of the Orange Book, collected and furnished by Bhaven Sampat. See also Fed. Trade Comm'n, Generic Drug Entry Prior to Patent Expiration vi (2002) [hereinafter Generic Drug Entry] (reporting three awards between 1984 and 1992), available at http://www.ftc.gov/os/2002/07/ genericdrugstudy.pdf.

${ }^{32}$ Mova Pharm. Corp. v. Shalala, 955 F. Supp. 128, 130 (D.D.C. 1997), aff'd, 140 F.3d 1060 (D.C. Cir. 1998) ("The language of the statute . . . is plain and unambiguous. It does not include a 'successful defense' requirement, and indeed it does not even require the institution of patent litigation.”); see also Granutec, Inc. v. Shalala, 46 U.S.P.Q.2d (BNA) 1398, 1401 (4th Cir. 1998) (similar).

${ }^{33}$ Ctr. for Drug Evaluation \& Research, FDA, Guidance for Industry: 180-Day Generic Drug Exclusivity Under the Hatch-Waxman Amendments to the Federal Food, Drug, and Cosmetic Act 4 (1998) (stating that "FDA will not enforce the 'successful defense' provisions" and "intends to formally remove" them from Code of Federal Regulations), available at http://www.fda. gov/downloads/Drugs/GuidanceComplianceRegulatoryInformation/Guidances/ucm079342.pdf.

${ }^{34}$ Letter from Gary Buehler, Dir. of Office of Generic Drugs, FDA, to Patricia Jaworski, IVAX Pharmaceuticals, Inc. 2-3 (June 23, 2006) (approving ANDA \#76-052 as to 5, 10, 20, and $40 \mathrm{mg}$ strengths, noting the absence of any suit, and awarding exclusivity as to these strengths). The text omits one complexity, that there was another generic drug maker that was first to file on one strength that represented about 10 percent of Zocor sales. Letter from Gary Buehler, Dir. of Office of Generic Drugs, FDA, to Abha Pant, Ranbaxy Laboratories Ltd. 2-3 (June 23, 2006) (approving ANDA \#76-285 as to $80 \mathrm{mg}$ strength, noting absence of any suit, and awarding exclusivity as to this strength). 


\section{Effects of 180-Day Exclusivity}

To better understand the role 180-day exclusivity plays in encouraging patent challenges and generic entry, we studied the circumstances in which generics actually obtained exclusivity to determine whether actual awards matched the paradigmatic case in which a generic firm invalidates a patent. As we explain in more detail below, this is seldom the case.

To do this, we collected every instance in which 180-day exclusivity was awarded by the FDA and triggered by the generic firm over a four-year period between 2005 and 2009. ${ }^{35}$ We dropped awards on three over-the-counter drugs $^{36}$ and several others where a close look at the award demonstrated its irrelevance. ${ }^{37}$ The final set contained forty-nine drugs, with some drugs having awards to multiple generic drug companies. Multiple awards arise where several firms share eligibility for exclusivity, generally because they filed ANDAs on the same day.

For each of these drugs, we determined which patent or patents supported the 180-day award using FDA approval letters, and assessed the circumstances of the award using a variety of sources. We categorized each award as a win in litigation, launch at risk, ${ }^{38}$ settlement, or no suit. ${ }^{39}$ Some of these were not straightforward to determine. In a few cases where a drug had awards to multiple generic firms, and the different firms received awards in different circumstances, we resolved the uncertainty in favor of the outcome that supported the exclusivity system. ${ }^{40}$

We found that for most drugs, the generic drug maker did little or nothing to earn the exclusivity award. Almost half of the awards (23) are no-suit awards, meaning that the generic firm didn't have to spend money on litigation or face uncertainty about the outcome of the suit. Indeed, in some cases

\footnotetext{
${ }^{35}$ In particular, the set contains every award in which exclusivity expired between October 2005 and October 2009.

${ }^{36}$ Generic competition in over-the-counter drugs takes an entirely different form. Consumption of generic prescription drugs, unlike over-the-counter drugs, is promoted by state automatic substitution laws and the reimbursement policies of insurance companies.

${ }^{37}$ For example, two involved an award for a drug that had already seen generic entry. In addition, for several drugs with separate exclusivity awards for different dosages, we coded the dosage for which exclusivity was awarded first.

${ }^{38}$ A generic launches "at risk" if the thirty-month stay of entry has expired but the lawsuit against it has not yet been resolved. If the generic nonetheless enters the market and ultimately loses the suit, it will owe damages that may far exceed what it made from marketing the drug. We coded a launch as "at risk" only if the launch occurred before the district court ruled.

${ }^{39}$ A "no suit" outcome is one in which the patentee did not file a lawsuit in response to a Paragraph IV ANDA filing on that patent, in effect conceding the right of the generic to enter. We counted the outcome as no suit in four cases in which there was a lawsuit on some patents but not on any patent that gave rise to the exclusivity award.

${ }^{40}$ For instance, where one generic settled and another won a case, we coded the drug as one involving a win.
} 
the basis for the award was a patent that was arguably irrelevant to the product described in the ANDA, in which case little or no effort was needed to develop a legal or design-around strategy. Another nine are settlements, which we reviewed in greater detail. None of these settlements did anything to open up the market to other generic entrants. ${ }^{41}$ Eight more were launches at risk. Only nine included a win by the generic firm, all but one of which included an invalidation or unenforceability determination as to at least one brand-name patent. ${ }^{42}$ These results are summarized in Table 1.

TABLE 1: AWARDS OF 180-DAY EXCLUSIVITY

\begin{tabular}{lcc}
\hline & Total & Blocking \\
\hline No suit & 23 & 12 \\
Settlement & 9 & 5 \\
Win in litigation & 9 & 5 \\
Launch at risk & 8 & 0 \\
Total & 49 & 22 \\
\hline
\end{tabular}

The fact that the 180-day generic exclusivity does not actually encourage many patent invalidations may come as a surprise. To be sure, we don't observe every instance in which the 180-day exclusivity might affect drug maker decisionmaking. We see only cases where the 180-day award is triggered. We don't observe instances in which the generic is eligible for the award but never actually received it, or where the award will eventually be triggered, but at a point later than the period of our study. The classic case of the latter situation is a settlement with delayed entry, in which the generic firm will

\footnotetext{
${ }^{41}$ One settlement, Lamictal CD, did provide for early generic entry, but the overall terms of the settlement did not promote entry. Lamictal CD is a chewable version of a blockbuster drug, Lamictal. At the time of settlement, annual sales of Lamictal CD were about \$50 million, compared to about $\$ 1$ billion for Lamictal tablets. Teva, the first filing generic for both versions, was sued-as to the same patent-for both drugs. In early 2005, Teva settled. Press Release, Teva Pharms. USA, Teva Announces Settlement of Lamictal Litigation with GlaxoSmithKline (Feb. 17, 2005). Under the settlement, Teva secured early (June 2005) entry with exclusivity on Lamictal $\mathrm{CD}$, and the early completion of the exclusivity period might have opened the way to other generic firms. (As it turned out, Teva's entry was delayed until June 2006, see Letter from Gary Buehler, Dir. of Office of Generic Drugs, FDA, to Philip Erickson, TEVA Pharmaceuticals USA (Aug. 30, 2006) (approving ANDA with exclusivity), but so far as it appears this was not due to the settlement.) At the same time, Teva accepted a delay of entry until July 2008 on the blockbuster version of the drug, six months prior to patent expiration. Thus the expiration of Teva's exclusivity coincided with the expiration of the Lamictal patent, blocking generic entry on the blockbuster version.

${ }^{42}$ Of the nine drugs, eight included a determination of invalidity or unenforceability and one centered on a judgment of noninfringement. In two of the eight coded as an invalidity case, the initial invalidity determination occurred on appeal to the Federal Circuit. (The district court had ruled in one of these two that the patent was valid and infringed, and in the other that the patent was valid but not infringed.)
} 
enter eventually, but has not done so yet. ${ }^{43}$ But we observe the set of cases in which 180-day exclusivity works the way it is supposed to. And there aren't very many of them.

Do these awards block entry by other generic firms? To answer this question, we need to know whether there are additional generic firms that would have entered before the end of the 180-day period but for the fact that they were blocked by the unexpired exclusivity. If a subsequent approval coincides with the end of exclusivity, the timing of approval is unlikely to be a coincidence. It is highly likely that the timing of entry was the result of exclusivity delay, even though we cannot rule out the possibility that some additional cause, such as technical problems raised by the FDA, would have prevented ANDA approval even without the delay. If a subsequent approval occurs long after the end of exclusivity, then the 180-day period is not a direct impediment to subsequent entry.

To determine this, we examined the approval dates of therapeutically equivalent generics for each drug. We coded a block if the subsequent approvals occurred on the day of exclusivity expiration or within ten days after that. ${ }^{44}$ For the 180-day awards on non-suit drugs, twelve blocked other generic approvals, with the effect of keeping prices high for longer than would otherwise be the case. Moreover, in most cases the award blocked approval of a large number of other generics, the earlier entry of which would have reduced prices even more. Five of the nine settlements also blocked subsequent approvals. In other words, when the exclusivity associated with the settling generic firm expired, there were immediate approvals of at least one other generic firm. Of the generic wins, five blocked subsequent generics. These results confirm the expectation that the exclusivity period does indeed impede subsequent entry.

\section{DRUG MAKER STRATEGIES AND POLICY RESPONSES}

As Paragraph IV certifications have continued to rise, ${ }^{45}$ brand-name drug makers have employed a variety of tactics to extend the duration of exclusiv-

\footnotetext{
${ }^{43}$ Consider, for example, the case of Xopenex, a popular asthma treatment. The first filer was sued over five method of use patents, with expiration dates ranging from January 2010 to August 2013, and one formulation patent expiring in March 2021. Shortly after the generic firm received FDA approval, the parties settled the litigation. The settlement agreement provides for a generic launch in August 2012. The generic firm retains exclusivity, without triggering it, in the meantime. For a discussion of the litigation history, see Dey, L.P. v. Sepracor, Inc., 595 F. Supp. 2d 355, 359 (D. Del. 2009).

${ }^{44} \mathrm{We}$ omitted one drug in which the end of exclusivity coincided with patent expiration, raising the possibility that the subsequent entrants had declined to challenge the patent, and hence been blocked from approval by the unexpired patent rather than the 180-day exclusivity period.

${ }^{45}$ See Hemphill \& Sampat, supra note 18.
} 
ity. Both of the unusual features of generic drug entry - the thirty-month stay of generic drug approval and the 180-day bounty-are vulnerable to manipulation. The long lead time needed to secure generic drug approval provides additional opportunities for abuse. These tactics have met with counter-measures-judicial, statutory, and regulatory - to curb their use, with varying degrees of success.

\section{A. Strategies for Delaying Generic Entry}

\section{Multiple Thirty-Month Stays}

One of the earliest strategies for avoiding generic entry focused on the operation of the thirty-month stay. Brand-name firms listed additional patents in the Orange Book after the generic firm filed its ANDA in order to secure multiple, overlapping stays for a single drug. This practice became known as "evergreening" 46 because the patentee could refresh its stay by periodically adding a new patent to the Orange Book, no matter how weak the patent or how little it related to the defendant's product. For example, in the case of Paxil, a blockbuster antidepressant, the brand-name drug maker initially listed a single patent in the Orange Book. A generic firm filed a Paragraph IV certification for the patent, which attracted a patent suit and triggered an initial stay. While that lawsuit was pending, the drug maker obtained additional patents and listed them on the Orange Book. These patents provided further ammunition in the fight with the generic firm. They obliged the generic firm to file additional Paragraph IV certifications, which triggered additional patent suits - and more stays, for a total of five overlapping stays that stretched out over sixty-five months. ${ }^{47}$ Paxil was far from unique. For six other drugs, brand-name drug makers secured multiple stays. ${ }^{48}$

Resolving the multiple stay problem entailed a mix of regulatory attention and legislative change. The FTC investigated and obtained antitrust consent

\footnotetext{
${ }^{46}$ For discussion of evergreening, see, e.g., Mark A. Lemley \& Kimberly A. Moore, Ending Abuse of Patent Continuations, 84 B.U. L. Rev. 63, 81-83 (2004). See also Lara J. Glasgow, Stretching the Limits of Intellectual Property Rights: Has the Pharmaceutical Industry Gone Too Far?, 41 IDEA 227, 233-35 (2001); Christine S. Paine, Brand-Name Drug Manufacturers Risk Antitrust Violations By Slowing Generic Production Through Patent Layering, 33 SETON HALL L. Rev. 479, 497 (2003); Frederick Tong, Widening the Bottleneck of Pharmaceutical Patent Exclusivity, 24 WhitTier L. Rev. 775, 787-88 (2003).

${ }^{47}$ Fed. Trade Comm'n, Generic Drug Entry, supra note 31, at 49.

${ }^{48} I d$. The FTC lists eight drugs including Paxil, but one of them, Platinol, involved a single stay caused by a late-added patent, rather than multiple stays. In addition to these drugs, the product-hopping conduct described in the next section can have the consequence of generating multiple automatic stays.
} 
decrees in several multiple stay cases, ${ }^{49}$ and publicized findings about the problem $^{50}$ that prompted an FDA decision to limit drug makers to a single stay for each ANDA, regardless of how many patents are listed in the Orange Book. ${ }^{51}$ In 2003, Congress passed legislation confirming that view. ${ }^{52}$ The problem has attracted private antitrust suits as well. ${ }^{53}$ But since 2003, evergreening of this form won't work for new cases.

\section{Product Switches}

A second brand-name tactic for extending the life of drug patents takes advantage of the long lead time needed for a generic firm to secure FDA approval of a competing drug, including establishing bioequivalence, making Paragraph IV certifications, and conducting litigation. By the time a generic drug is approved, the brand-name firm may have developed a new formulation-for example, a tablet instead of a capsule-and switched customers from the old drug to the new drug. Developing a generic version of the new drug then requires the generic firm to go through the process all over again, with further delays. In the meantime, the generic firm may sell its version of the old drug, but that is often small comfort because pharmacists cannot substitute the old drug for the new brand-name drug. ${ }^{54}$

Not all product switches are created equal. A single enantiomer version, or once-a-day formulation, may offer significant improvements over the original, and the differences may lead patients and doctors to prefer the new drug. But product switches that involve significant changes in the product generally re-

${ }^{49}$ See, e.g., Biovail Corp., FTC Docket No. C-4060, 2002 WL 727033 (Apr. 23, 2002); Bristol-Myers Squibb Co., FTC Docket No. C-4076, 2003 WL 25797221 (Apr. 14, 2003) (describing improper multiple stays).

${ }^{50}$ Fed. Trade Comm'n, Generic Drug Entry supra note 31, at ii-v, 48-52.

${ }^{51}$ Applications for FDA Approval to Market a New Drug: Patent Submission and Listing Requirements and Application of 30-Month Stays on Approval of Abbreviated New Drug Applications Certifying that a Patent Claiming a Drug Is Invalid or Will Not Be Infringed; Final Rule, 21 C.F.R. $\S 314$.

52 Medicare Prescription Drug, Improvement, and Modernization Act of 2003, Pub. L. No. 108-173, §1101(a)(2)(A)(ii), 117 Stat. 2066, 2449-50.

${ }^{53}$ The multiple stays in Paxil were the subject of antitrust class action suits by indirect and direct purchasers that resulted in settlements of \$65 million and \$100 million, respectively. See Nichols v. SmithKline Beecham Corp., No. Civ. A. 00-6222, 2005 WL 950616, at *1, *26-27 (E.D. Pa. Apr. 22, 2005) (indirect); Stop \& Shop Supermarket Co. v. SmithKline Beecham Corp., No. Civ. A. 03-4578, 2005 WL 1213926, at *1 (E.D. Pa. May 19, 2005) (direct). A competitor claim was recently settled too. Press Release, GlaxoSmithKline, GlaxoSmithKline Legal Update (July 15, 2010) (reporting that antitrust litigation with Apotex over Paxil is now "fully resolved").

${ }^{54}$ For analyses, see 1 Herbert Hovenkamp et Al., IP And Antitrust $\$ 15.3 \mathrm{c} 1$ (2d ed. 2010); Stacey L. Dogan \& Mark A. Lemley, Antitrust Law and Regulatory Gaming, 87 Tex. L. Rev. 685, 709-17 (2009); Steve D. Shadowen et al., Anticompetitive Product Changes in the Pharmaceutical Industry, 41 Rutgers L.J. 1 (2009); Robin Feldman, Rethinking Patent RigHTs ch. 5 (forthcoming 2012). 
quire a new NDA by the brand-name company, which means that they are not a very useful tool for raising rivals' costs. Manipulation of the switch is more troubling if the improvement on the original drug is less significant: if the new drug is bioequivalent to the old, no new clinical studies are required. In the extreme case, there is no improvement, and the product design change is made purely to create an incompatibility between the new patented product and the generic product that avoids competition.

In some cases, the drug maker's product-switching or "product-hopping" conduct goes even further. For example, the drug maker, after accomplishing the switch, may go to great lengths to withdraw the older drug from the market, making it more difficult for pharmacists to fill prescriptions for the old drug using the generic product. ${ }^{55}$ Another tactic is to execute multiple switches, for example, from a capsule form to a tablet form, and then a second switch-as the generic firm again closes in on approval-to a third, slightly different tablet form. ${ }^{56}$ The second (or third, or fourth) switch compounds the consumer harm of the first switch.

The primary countermeasure in response to product hopping has been private antitrust enforcement. Courts applying antitrust law are understandably skeptical of claims that purported innovations have harmed consumers, but not every claim of innovation is entitled to deference, and the proper legal standard is a matter of ongoing dispute. ${ }^{57}$ In the leading case, the plaintiff

\footnotetext{
${ }^{55}$ For example, consider brand-name drug maker Abbott's defense of Tricor, a product that was originally approved in capsule form but later approved in a tablet formulation. Upon tablet approval, Abbott took a series of steps to suppress capsule sales, above and beyond cutting off its own capsule sales. Abbott's tactics included reacquiring the remaining stock of TriCor capsules and switching the National Drug Data File's code for TriCor capsules to "obsolete." Abbott Labs. v. Teva Pharms. USA, Inc., 432 F. Supp. 2d 408, 416 (D. Del. 2006). The code switch converted Teva's generic version of the old capsule product - the only version of the capsule product still available - to a brand-name product in the view of some health plans. That lowered the reimbursement rate and inhibited pharmacies from requesting to switch new tablet prescriptions to Teva's capsule product. It also prevented pharmacists from automatically substituting the generic capsules for Abbott capsule prescriptions under state generic substitution laws. See Second Amended Answer, Affirmative Defenses, and Counterclaims, Abbott Labs. v. Teva Pharms. USA, Inc., No. 02-1512, 2005 WL 6155984 (D. Del. July 29, 2005); First Amended Counterclaims at 9, Abbott Labs. v. Impax Labs., Inc., No. 03-120, 2005 WL 6155872 (D. Del. Sept. 30, 2005); Teva Pharms. USA, Inc. v. Abbott Labs., 580 F. Supp. 2d 345, 355 (D. Del. 2008) (noting plaintiffs' allegation that code change resulted in higher insurance copayment). Teva's sales were thus limited to those few doctors who wrote prescriptions specific to Teva's own (Lofibra) brand of the product.

A similar strategy is for the brand owner to deactivate the NDA with the FDA, forcing the ANDA filer to seek a declaration from the FDA that the original drug approval was not withdrawn for safety and efficacy reasons.

${ }^{56}$ Abbott Labs, 432 F. Supp. 2d at 416-17.

57 Compare id. with Walgreen Co. v. AstraZeneca Pharms., 534 F. Supp. 2d 146 (D.D.C. 2008) (dismissing antitrust claim involving switch from Prilosec to Nexium); see United States v. Microsoft Corp., 253 F.3d 34, 65 (D.C. Cir. 2001) (per curiam) (en banc) (noting that courts are skeptical of antitrust claims based on product design changes because "firms routinely inno-
} 
presented evidence that multiple switches with no significant benefits for consumers, combined with withdrawal of the older drug from the market, were made specifically to fend off competition from generic drug makers. The case reached trial, and the brand-name firm settled. ${ }^{58}$ The court's willingness to consider the product-hopping claim may have curbed similarly egregious behavior by other brand-name firms.

\section{Manipulation of the 180-Day Bounty}

Multiple stays and product hopping are unilateral actions by a brand-name firm made at the expense of the generic firm. Manipulation of the 180-day bounty, by contrast, relies on collusion between the brand-name and generic firm. As discussed in Part I, a brand-name drug maker has a lot at risk in patent litigation with a generic firm. If a court strikes down the brand-name patent, the result is a sharp decline in profit. A generic firm eligible for the 180-day bounty, for its part, has a lot to lose too. Its potential generic exclusivity disappears if the court decides that the patent is valid and infringed.

These complementary risks set the stage for a peculiar form of non-aggression pact. Both the brand-name drug maker and the generic firm gain by settling the pending patent litigation without resolving the status of either the patent or the generic exclusivity. The brand-name firm is much better off because it has eliminated a near-term threat to its monopoly. And because the FDA regulates entry without evaluating the scope or strength of the relevant patents, settling that suit will enable it to keep even a dubious patent intact for some period of time. The generic drug maker is also much better off. When it eventually enters the market, at a time set by mutual agreement of the drug makers, it will reap the 180-day bounty. ${ }^{59}$ Thanks to the lack of a successful defense requirement, the generic firm need not win a patent suit to receive the bounty. Consumers, however, suffer from the elimination of a chance at early generic entry, as explained below, and from higher prices during the 180 days of generic exclusivity.

\footnotetext{
vate in the hope of appealing to consumers, sometimes in the process making their products incompatible with those of rivals," and imposing liability on dominant firms that do so would "inevitably deter a certain amount of innovation"); 1 HeRBert HovenKamP ET AL., supra note 54 , at $\S 12.3$ e. For an argument that any plausible claim of benefit must defeat an antitrust claim for product hopping, see Richard Gilbert, Holding Innovation to an Antitrust Standard, CoMPETITION POL'y INT'L, Spring 2007, at 47.

${ }^{58}$ Abbott Labs, 432 F. Supp. 2d at 434 (denying motion to dismiss); Teva Pharms. USA, Inc. v. Abbott Labs., 580 F. Supp. 2d 345, 369 (D. Del. 2008) (denying summary judgment in part). For endorsement of antitrust liability in this circumstance, see Dogan \& Lemley, supra note 54. For an argument that product hopping should violate antitrust laws, but using a different approach than Abbott Labs, see generally Jessie Cheng, Note, An Antitrust Analysis of Product Hopping in the Pharmaceutical Industry, 108 Colum. L. Rev. 1471 (2008).

${ }^{59} \mathrm{An}$ exception is a settlement that provides for entry upon patent expiration. In that case, the generic firm enjoys no exclusivity because exclusivity disappears when the patent expires.
} 
Such non-aggression pacts have become common. Since the 1984 passage of the Hatch-Waxman Act, dozens of settlements of drug patent litigation have included retained exclusivity. ${ }^{60}$ Some of these settlements include an additional troubling feature: a cash payment by the brand-name firm to the generic firm to secure an even later generic entry date. Settlements with cash payments have received a great deal of attention, creating enormous controversy and a large literature considering their effects and how the law should treat them. ${ }^{61}$ Other settlements have retained exclusivity but no cash payments.

Settlements with retained exclusivity delay entry by two mechanisms. First, later filers-generic drug makers that file ANDAs with Paragraph IV certifications after the first filer-are blocked from FDA approval while the first filer's bounty is pending. That is because the approval of later generic applicants is delayed until 180 days after the date of "first commercial marketing" by the first filer, ${ }^{62}$ which in turn is delayed thanks to the settlement. The delay is limited by the possible forfeiture of exclusivity, as explained below. But settlement itself does not amount to such a forfeiture.

Breaking through the resulting bottleneck is difficult, costly, and time-consuming. Under current law, the later filer can force the first filer to use the

${ }^{60}$ C. Scott Hemphill, An Aggregate Approach to Antitrust: Using New Data and Rulemaking to Preserve Drug Competition, 109 Colum. L. Rev. 629, 651-55 (2009) [hereinafter Aggregate Approach].

${ }^{61}$ For analyses of the controversy, see, e.g., 1 HovenkAMP ET AL., supra note 54, § 15.3a1; Robin Feldman, The Role of Science in Law 167 (2009); Jeremy Bulow, The Gaming of Pharmaceutical Patents, in 4 Innovation Policy and the Economy 145 (Adam B. Jaffe et al. eds., 2004); Roger D. Blair \& Thomas F. Cotter, Are Settlements of Patent Disputes Illegal Per Se?, 47 Antitrust Bull. 491 (2002); Michael A. Carrier, Unsettling Drug Patent Settlements: A Framework for Presumptive Illegality, 108 Мich. L. Rev. 37 (2009); Daniel A. Crane, Exit Payments in Settlement of Patent Infringement Lawsuits: Antitrust Rules and Economic Implications, 54 Fla. L. Rev. 747 (2002); Bret Dickey et al., An Economic Assessment of Patent Settlements in the Pharmaceutical Industry, 19 Annals Health L. 367 (2010); Joseph Farrell \& Carl Shapiro, How Strong Are Weak Patents?, 98 Am. Econ. Rev. 1347 (2008); Hemphill, Aggregate Approach, supra note 60; C. Scott Hemphill, Paying for Delay: Pharmaceutical Patent Settlement as a Regulatory Design Problem, 81 N.Y.U. L. Rev. 1553 (2006) [hereinafter Paying for Delay]; Hovenkamp et al., supra note 8; Mark A. Lemley \& Carl Shapiro, Probabilistic Patents, 19 J. Econ. Persps., Spring 2005, at 75; Kevin D. McDonald, Hatch-Waxman Patent Settlements and Antitrust: On "Probabilistic" Patent Rights and False Positives, Antitrust, Spring 2003, at 68; Maureen A. O'Rourke \& Joseph F. Brodley, An Incentives Approach to Patent Settlements, 87 Minn. L. Rev. 1767 (2003); Catherine J.K. Sandoval, Pharmaceutical Reverse Payment Settlements: Presumptions, Procedural Burdens, and Covenants Not to Sue Generic Drug Manufacturers, 26 Santa Clara Computer \& High Tech. L.J. 141 (2009); Marc G. Schildkraut, Patent-Splitting Settlements and the Reverse Payment Fallacy, 71 AnTitrust L.J. 1033 (2004); Carl Shapiro, Antitrust Limits to Patent Settlements, 34 RAND J. Econ. 391 (2003); Robert D. Willig \& John P. Bigelow, Antitrust Policy Toward Agreements that Settle Patent Litigation, 49 Antitrust Bull. 655 (2004).

${ }^{62}$ See 21 U.S.C. $\$ 355(\mathrm{j})(5)(\mathrm{B})(\mathrm{iv})(\mathrm{I})$. The description in text applies to new NDAs. For a comparison of this regime to the pre-MMA regime, see Hemphill, Aggregate Approach, supra note 60 , at $658-59$. 
bounty (i.e., enter with exclusivity) or else lose it, but only if the later filer wins a patent suit of its own. That is difficult and time-consuming and, to make matters worse, it is not enough to win in the district court. Only an appellate win by the later filer triggers the first filer's obligation to enter with exclusivity, which it must do within seventy-five days or else forfeit the bounty. ${ }^{63}$ The resulting delay from this process-file the ANDA, conduct the district court suit, win the appeal, wait until just before the end of seventy-five days, then wait another 180 days - can easily stretch to several years. ${ }^{64}$ Moreover, in some cases, the settlement between the brand-name firm and the first filer permits the first filer to launch upon FDA approval or launch of the later filer's product, further reducing the incentive to pursue this strategy. In the meantime, consumers pay monopoly prices.

This account presumes that there is a patent lawsuit between the brandname firm and the later filer. Often, that cannot be taken for granted because the brand-name firm declines to sue the later filer, even if it sued the first filer. Without a suit, the later filer is bottled up behind the first filer, unable to secure FDA approval. In response, some generic firms file declaratory judgment suits in an effort to trigger (eventually) the first filer's use-it-or-lose-it obligation. A declaratory judgment action, however, is a chancy thing, because there is often a dispute about whether the generic firm has standing to bring its suit. ${ }^{65}$ That complication makes this route an even more time-consuming, costly, and uncertain affair.

\footnotetext{
${ }^{63} 21$ U.S.C. $\S 355(\mathrm{j})(5)(\mathrm{D})(\mathrm{i})(\mathrm{I})(\mathrm{bb})(\mathrm{AA})$.
}

${ }^{64}$ See Dey, L.P. v. Sepracor, Inc., 595 F. Supp. 2d 355, 357 n.1 (D. Del. 2009) (describing this outcome). This description applies to drugs with new ANDAs. For old ANDAs, the result of a later filer's appellate win is not a forfeiture but a triggering of the first filer's exclusivity. Medicare Prescription Drug, Improvement, and Modernization Act of 2003, Pub. L. No. 108-173, $\S 1102$ (b)(3), 117 Stat. 2066, 2460 (2003) (codified as a note to 21 U.S.C. § 355).

${ }^{65}$ Prior to 2007, the Federal Circuit took the view that declaratory judgment actions were inappropriate in these cases. After the Supreme Court cast serious doubt on this view in MedImmune, Inc. v. Genentech, Inc., 549 U.S. 118, 132 n.11 (2007), the Federal Circuit changed course. Today, some cases are allowed to move forward, while others are not. Compare Teva Pharms. USA, Inc. v. Eisai Co. 620 F.3d 1341 (Fed. Cir. 2010) (generic firm has standing); Caraco Pharm. Labs., Ltd., v. Forest Labs., Inc., 527 F.3d 1278, 1288, 1297 (Fed Cir. 2008) (same); Teva Pharms. USA, Inc. v. Novartis Pharms. Corp., 482 F.3d 1330, 1334 (Fed. Cir. 2007) (same); Pfizer Inc. v. Apotex Inc., 726 F. Supp. 2d 921 (N.D. Ill. 2010) (same); Dey, 595 F. Supp. 2d 355 (same); with Janssen Pharmaceutica, N.V. v. Apotex, Inc., 540 F.3d 1353, 1362-64 (Fed Cir. 2008) (generic firm lacks standing); Merck \& Co. v. Apotex, Inc., 292 Fed. App'x 38 (Fed. Cir. 2008) (per curiam) (same); Merck \& Co. v. Apotex, Inc., 488 F. Supp. 2d 418 (D. Del. 2007), vacated as moot, 287 Fed. App'x 884 (Fed. Cir. 2008) (same). See also Dr. Reddy's Labs., Ltd. v. AstraZeneca AB, No. 08-2496, 2008 WL 4056533 (D.N.J. 2008) (generic firm lacks standing as to some patents), order vacated on reconsideration, 2009 WL 3241699 (D.N.J. 2009) (denying dismissal); Ivax Pharms., Inc. v. AstraZeneca AB, No. 08-2165, 2008 WL 4056518 (D.N.J. 2008), order vacated in part on reconsideration, 2009 WL 3208656 (D.N.J. 2009) (same). This time-consuming litigation over standing delays generic entry even when it is ultimately resolved in favor of the generic firm. 
Second, retained exclusivity makes a settling generic firm more willing to accept a settlement with a greater delay. As explained above, the exclusivity period is quite valuable. The value of this opportunity, however, is discounted by the uncertainty that the generic firm might lose the litigation, and thus never enjoy the exclusivity period. A brand-name firm's agreement to drop the patent fight is valuable to the generic firm because it raises the probability of enjoying the exclusivity. It is therefore willing to trade a later entry date for the better chance to enjoy the 180 days. ${ }^{66}$ As one generic drug CEO has explained, "Elimination of the risk of losing by the generic company is not just a payment in and of itself, but the primary form of payment in Hatch-Waxman settlements." ${ }^{67}$

This effect is quite different from what we ordinarily observe in patent litigation. The ability to settle with retained exclusivity disrupts the alignment of interests between the generic firm and consumers. Ordinarily, a late entry date is bad for consumers but also bad for an alleged infringer, whose profits are (roughly) proportional to the amount of the time on the market. The infringer can therefore be expected to fight for an earlier entry date. Under settlement with retained exclusivity, by contrast, the profits from entry are highly nonlinear. Most of the profits are earned during the exclusivity period. As a result, the generic firm cares more about protecting its 180-day duopoly entitlement, and less about when exactly that entry occurs. It is therefore much more willing to accept a later entry date than it would be if settlement did not preserve exclusivity.

${ }^{66}$ For analyses, see Scott A. Backus, Reversing Course on Reverse Payment Settlements in the Pharmaceutical Industry: Has Schering-Plough Created the Blueprint for Defensible Antitrust Violations?, 60 Окца. L. Rev. 375, 414-16 (2007); Michael A. Carrier, A Real-World Analysis of Pharmaceutical Settlements: The Missing Dimension of Product Hopping, 62 FLA. L. Rev. 1009, 1032-33 (2010); Michael A. Carrier, Solving the Drug Settlement Problem: The Legislative Approach, 41 Rutgers L.J. 83, 93 (2009); Joshua P. Davis, Applying Litigation Economics to Patent Settlements: Why Reverse Payments Should Be Per Se Illegal, 41 Rutgers L.J. 255, 304-05 (2009); Hemphill, Aggregate Approach, supra note 60, at 651-53; Hemphill, Paying for Delay, supra note 61, at 1588-94; Ankur N. Patel, Comment, Delayed Access to Generic Medicine: A Comment on the Hatch-Waxman Act and the "Approval Bottleneck," 78 FordHAm L. REv. 1075, 1096 (2009).

An extreme version of this effect occurs when the brand-name firm's forbearance extends to an agreement not to launch an authorized generic product during the exclusivity period. For a discussion, see Fed. Trade Comm'n, Authorized Generics: An Interim Report ch. 2, 1-10 (2009), available at $\mathrm{http} / / / \mathrm{www} . f t c . g o v / o s / 2009 / 06 / P 062105$ authorizedgenericsreport.pdf.

${ }^{67}$ Protecting Consumer Access to Generic Drugs Act of 2009: Hearing on H.R. 1706 Before the Subcomm. on Commerce, Trade, and Consumer Protection of the H. Comm. on Energy \& Commerce, 111th Cong. (2009) (statement of Bernard Sherman, CEO, Apotex, Inc.) [hereinafter Sherman, Statement at H.R. 1706 Hearing]. 


\section{B. Policy Responses to Manipulation of the 180-Day Bounty}

There are several possible policy responses to non-aggression pacts and the resulting blocking of later filers. ${ }^{68}$ An intervention is possible before, during, or after the Paragraph IV challenge and award of a bounty. Before the challenge occurs, we can limit the set of patents that can provide a basis for the bounty in the first place. Once the challenge occurs, we can either narrow the types of generic-firm conduct that qualify for exclusivity or reduce the effect of exclusivity on later filers. After the challenge is complete, we can use antitrust law to deter and neutralize the effect of manipulation.

\section{After the Challenge}

Most of the current policy attention to this issue concentrates on ex post measures. Private plaintiffs and government enforcers have looked mainly to antitrust law to clean up and, it is hoped, deter manipulation of the bounty. The major focus has been "pay-for-delay" settlements in which the brandname firm not only reaches a non-aggression pact with the generic firm, but makes a large additional cash payment to the generic firm in exchange for delaying the entry date. In these cases, the cash payment has been the centerpiece. The effect of manipulation of the 180-day bounty on later filers has also played a role in some cases. ${ }^{69}$

Antitrust law has so far met with poor to mixed results in cases with a large cash payment. ${ }^{70}$ New legislation has been proposed to clarify that pay-fordelay settlements violate either the Clayton Act or the FTC Act. ${ }^{71}$ We think

\footnotetext{
${ }^{68}$ Supporters of the pharmaceutical companies have sometimes argued that there is no problem with paying competitors to stay out of the market, often because doing so protects the interests of patent owners. As we have explained elsewhere, we think that argument is wrong. See, e.g., Hemphill, Paying for Delay, supra note 61; Hovenkamp et al., supra note 8. But manipulation of the bounty is a distinct offense against competitive entry. Even for those readers who resist antitrust liability for such settlements, our proposal should hold significant appeal.

${ }^{69}$ See, e.g., King Drug Co. of Florence, Inc. v. Cephalon, Inc., 702 F. Supp. 2d 514, 535-36 (E.D. Pa. 2010) (denying motion to dismiss, in part, because plaintiffs alleged that agreement created a bottleneck that blocked subsequent filers).

70 The Second and Federal Circuits have declined as a matter of law to impose antitrust liability even in cases in which the payment was quite large. See Ark. Carpenters Health \& Welfare Fund v. Bayer AG, 604 F.3d 98, 110 (2d Cir. 2010) (per curiam); In re Ciprofloxacin Hydrochloride Antitrust Litig., 544 F.3d 1323, 1341 (Fed. Cir. 2008). The Eleventh Circuit has applied a somewhat different standard, but with substantial deference to the patent and the settlement. Schering-Plough Corp. v. FTC, 402 F.3d 1056, 1076 (11th Cir. 2005); Valley Drug Co. v. Geneva Pharms., Inc., 344 F.3d 1294 (11th Cir. 2003). The Sixth Circuit has concluded that some settlements are per se illegal. See In re Cardizem CD Antitrust Litig., 332 F.3d 896, 908 (6th Cir. 2003); see also Andrx Pharms., Inc. v. Biovail Corp. Int'1, 256 F.3d 799, 809-12 (D.C. Cir. 2001) (reaching similar conclusion in dicta); Arkansas Carpenters, 604 F.3d at 108-10 (opinion by Second Circuit panel, explaining that the panel was bound by Circuit precedent, and urging reconsideration of that view).

${ }^{71}$ See, e.g., Preserve Access to Affordable Generics Act, S. 369, 111th Cong. (2010).
} 
that pay-for-delay settlements violate existing antitrust law, including settlements that take the form of a non-aggression pact that manipulates the exclusivity period..$^{72}$ These issues have been extensively discussed by us and others, and we do not repeat those arguments here. The struggle to establish liability in cash payment cases, however, means that a standalone manipulation case without a cash payment might seem to be a risky bet for an antitrust plaintiff in the near term.

\section{Before the Challenge}

A second response is to narrow the set of patents that are subject to Paragraph IV challenges, and hence 180-day awards. The FDA implemented one solution along these lines when it narrowed the set of patents that could be listed on the Orange Book by ruling out patents on chemical variants different from the approved drug. ${ }^{73}$ The 2003 statutory amendments to the Hatch-Waxman Act might be thought to offer another step in this direction, by providing for forfeiture of exclusivity if the patent that is the basis for the award is delisted from the Orange Book-for example, because the patent does not sufficiently pertain to the approved drug product to be eligible for inclusion. ${ }^{74}$ However, the D.C. Circuit concluded that, despite this language, even a delisting cannot deprive the generic firm of its continued entitlement to exclusivity. ${ }^{75}$ In any event, these measures leave unaffected a large number of unearned awards, particularly since the listing of a patent on the Orange Book is a ministerial act, not one that involves any evaluation by the FDA of the relevance of the patent. ${ }^{76}$

A more ambitious proposal would be to limit the patent award itself, by evaluating drug patents before they become the basis for 180-day awards. Patents are not carefully scrutinized by the Patent Office before they are issued. ${ }^{77}$ That default could be altered for drug patents, for example, by providing for reexamination of every patent that receives a Paragraph IV

\footnotetext{
${ }^{72}$ Hemphill, Paying for Delay, supra note 61, at 1596; Hovenkamp et al., supra note 8.

${ }^{73}$ Applications for FDA Approval to Market a New Drug: Patent Submission and Listing Requirements and Application of 30-Month Stays on Approval of Abbreviated New Drug Applications Certifying that a Patent Claiming a Drug Is Invalid or Will Not Be Infringed; Final Rule, 21 C.F.R. $\S 314$.

7421 U.S.C. $\S 355(\mathrm{j})(5)(\mathrm{D})(\mathrm{i})(\mathrm{I})(\mathrm{bb})(\mathrm{CC})$. Under the pre-MMA regime, which contained no similar forfeiture provision, ANDA filers remained eligible for the exclusivity despite delisting, as in the case of Zocor. Ranbaxy Labs. Ltd. v. Leavitt, 469 F.3d 120, 126 (D.C. Cir. 2006).

75 Teva Pharms. USA, Inc. v. Sebelius, 595 F.3d 1303, 1318 (D.C. Cir. 2010).

76 See, e.g., In re Buspirone Patent Litig., 185 F. Supp. 2d 363, 369-70 (S.D.N.Y. 2002); Watson Pharms., Inc. v. Henney, 194 F. Supp. 2d 442, 445 (D. Md. 2001); Mylan Pharms., Inc. v. Thompson, 139 F. Supp. 2d 1, 10-11 (D.D.C. 2001), rev'd on other grounds, 268 F.3d 1323 (Fed. Cir. 2001).

${ }^{77}$ Mark A. Lemley, Rational Ignorance at the Patent Office, 95 Nw. U. L. Rev. 1495 (2001).
} 
certification, ${ }^{78}$ or even every patent in the Orange Book. Reexamination has the advantage that, unlike a private suit, it cannot be settled once it has begun. ${ }^{79}$ And this additional scrutiny would be consistent with proposals that the PTO focus more attention on the most important patents. ${ }^{80}$ But it cannot solve the whole problem. The PTO is oriented towards granting, not denying, patents. ${ }^{81}$ The reexamination process is limited to certain types of prior art, and excludes things like prior sales or uses that are often the most important types of art. ${ }^{82}$ And the PTO cannot assess infringement as opposed to validity.

\section{During the Challenge}

The third route is to reduce manipulation of the 180-day bounty by altering its source, the award procedure contained in the Hatch-Waxman Act. For example, one somewhat drastic solution is to simply eliminate the bounty. ${ }^{83} \mathrm{We}$ don't go that far, though some of the arguments about our proposal, discussed in Part IV, also apply to elimination.

We propose to mend the bounty, not end it. Our basic proposal is to narrow the availability of the bounty to those generic drug makers that have done something substantial to earn it. Our inspiration is the successful defense regime initially maintained by the FDA. This idea has been largely neglected, despite its having been used by the FDA in the early years of the HatchWaxman Act. ${ }^{84}$ The neglect is even more surprising given one powerful source of support for such a change: Senator Orrin Hatch. Aside from being a prime mover behind the Hatch-Waxman Act, Hatch was an active participant in the development of the 2003 legislative amendments. During the revision

${ }^{78}$ For a proposal along these lines, see Gregory Dolin, Reverse Settlements as Patent Invalidity Signals (SSRN Working Paper Series, 2010), available at http://ssrn.com/abstract=1675947.

7935 U.S.C. $\S \S 301-305$.

80 See, e.g., Doug Lichtman \& Mark A. Lemley, Rethinking Patent Law's Presumption of Validity, 60 Stan. L. Rev. 45 (2007); Mark A. Lemley et al., What to Do About Bad Patents, REG., Winter 2005-2006, at 10.

${ }^{81}$ See, e.g., Lichtman \& Lemley, supra note 80 , at 52-56.

8235 U.S.C. $\S 301$.

${ }^{83}$ See, e.g., Patel, supra note 66, at 1113-14; Alfred B. Engelberg, Special Patent Provisions for Pharmaceuticals: Have They Outlived Their Usefulness?, 39 IDEA 389, 425 (1999); see also Examining the Senate and House Versions of the "Greater Access to Affordable Pharmaceuticals Act of 2003": Hearing Before the S. Comm. on the Judiciary, 108th Cong. (2003) (statement of Robert Armitage, Vice President \& General Counsel, Eli Lilly and Company) (proposing a severe limitation on availability of exclusivity).

${ }^{84}$ See, e.g., FDA, Guidance for Industry 1 (1988) [hereinafter 1988 FDA Guidance] (taking view that Congress intended 180-day provision to be limited to instances of successful litigation), available at http://www.fda.gov/downloads/Drugs/GuidanceComplianceRegulatoryInformation/Guidances/ucm075007.pdf; Abbreviated New Drug Application Regulations; Patent and Exclusivity Provisions, Final Rule, 59 Fed. Reg. 50,338, 50,353 (Oct. 3, 1994). An exception to the neglect is Robin Feldman, who has noted that an alteration of the exclusivity rules to apply only if the generic challenger wins on the merits would amount to a return to the successful defense regime. Feldman, supra note 61, at 165. 
process, he often criticized the "almost unbelievable advantage" given to first filers, ${ }^{85}$ and repeatedly urged a version of the successful defense regime. ${ }^{86}$ The next Part takes up how to accomplish a partial restoration of that regime.

\section{AN EARNED EXCLUSIVITY PROPOSAL}

The core of our proposal is that to earn the bounty, a first-filing generic drug maker must exert significant effort to secure early generic entry, with the end result of achieving entry without delay. For example, if the generic firm files a Paragraph IV certification, is sued, and wins the suit, it receives the bounty. If the generic firm instead loses the suit, it loses the exclusivity. Nor can it receive the bounty if it settles for delayed entry.

We do not propose an exact return to the successful defense requirement. ${ }^{87}$ That would be difficult as a formal matter, since the statute has changed in important ways since 1984. Nor do we challenge the D.C. Circuit ruling that rejected successful defense as an interpretation of the original Hatch-Waxman Act; our proposal is focused on the current (and different) statutory scheme. As a substantive matter, moreover, we would grant exclusivity in circumstances where the FDA did not. The first generic would receive the bounty if it successfully defeats the patent owner, obtains a settlement that permits immediate entry, or receives FDA approval having never been sued.

An easy way to implement our proposal is simply to narrow the set of first filers eligible for the bounty. Under current law, only a "first applicant" is eligible. A first applicant is "an applicant that, on the first day on which a substantially complete application containing a [Paragraph IV certification] is submitted for approval of a drug, submits a substantially complete application that contains and lawfully maintains a [Paragraph IV certification] for the drug." 88 It is not enough simply to have applied under the law; the Paragraph IV certification must be "lawfully maintained." If, for example, a generic firm

\footnotetext{
${ }^{85}$ Legislative and Regulatory Responses to the FTC Study on Barriers to Entry in the Pharmaceutical Marketplace: Hearing Before the S. Comm. on the Judiciary, 108th Cong. (2003) (statement of Sen. Orrin Hatch).

86 "[I]f we are to legislate in this area, why don't we consider overriding Mova and reinstate the old successful defense requirement?" Id. See also 149 Cong. Rec. S8686, S8692 (2003), 2003 WL 21485369; 149 ConG. Rec. S8169, S8195 (2003), 2003 WL 21414398 (proposal under consideration "appears to retain a feature of the current system that grants the 180-day marketing exclusivity period to first filers of generic drug applications rather than those applicants actually successful in defeating the patents of pioneer drug firms"). It bears noting, however, that Hatch has expressed sympathy for a variety of proposals that promote entry by later filers, some of which diverge from a return to successful defense.

${ }^{87}$ For such a suggestion, see Timothy Chen Saulsbury, Curbing Pay for Delay: The Case for a Legislative Solution (Jan. 8, 2010) (unpublished manuscript) (on file with author).

8821 U.S.C. $\$ 355(\mathrm{j})(5)(\mathrm{B})(\mathrm{iv})(\mathrm{II})(\mathrm{bb})$ (emphasis added). The inartful language here is intended to treat all applicants that file on the first day as another first filer.
} 
loses a Paragraph IV challenge in court, it may no longer lawfully maintain the certification. ${ }^{89}$

What if the generic firm instead settles the suit in a manner that delays entry? In this situation, too, we think the Paragraph IV certification is no longer lawfully maintained within the meaning of the statute, because the generic firm is no longer pressing its claim. That interpretation is consistent with the statutory text, though courts to date have not reached the question. ${ }^{90} \mathrm{We}$ propose that the law be clarified to make this interpretation explicit: if the generic firm settles, it is no longer lawfully maintaining its certification. The FDA has not yet conclusively resolved this question, ${ }^{91}$ and could accomplish this clarification by issuing a rule that interprets the scope of "lawfully main-

${ }^{89}$ Letter from Gary Buehler, Dir. of Office of Generic Drugs, FDA, to [Unnamed] ANDA Applicant (Oct. 28, 2008) (interpreting "lawfully maintains" in the course of determining 180day exclusivity for generic version of Cosopt), available at http://www.fda.gov/downloads/ AboutFDA/CentersOffices/CenterforDrugEvaluationandResearch/ucm119602.pdf. The ANDA filer must instead convert the certification to Paragraph III, which acknowledges the validity and infringement of the patent, in which case the FDA must wait until patent expiration to approve the ANDA. For a discussion of "lawfully maintained," see David E. Korn et al., A New History and Discussion of 180-Day Exclusivity, 64 Food \& Drug L.J. 335, 346-47 (2009).

${ }^{90}$ See, e.g., David Bickart, The Hatch-Waxman Act, in Developments in Pharmaceutical and Biotech Patent Law 205, 274 (Practising Law Institute 2008) (noting this "conceivabl[e]" interpretation); Erica N. Andersen, Note, Schering the Market: Analyzing the Debate over Reverse-Payment Settlements in the Wake of the Medicare Modernization Act of 2003 and In re Tamoxifen Citrate Litigation, 93 Iowa L. Rev. 1015, 1051-52 (2008) (advocating this approach); Hemphill, Aggregate Approach, supra note 60, at 660 n.125.

${ }^{91}$ In a 2008 letter granting exclusivity for generic granisetron, the FDA touched on but did not answer this question. See Letter from Gary J. Buehler, Dir., Office of Generic Drugs, FDA, to Marc A. Goshko, Executive Dir., Teva N. Am. 5 (Jan. 17, 2008), available at http://www.fda. gov/downloads/Drugs/DevelopmentApprovalProcess/HowDrugsareDevelopedandApproved/ApprovalApplications/AbbreviatedNewDrugApplicationANDAGenerics/UCM151237.pdf. In that letter, the FDA concluded that the generic firm had not forfeited exclusivity under certain "failure to market" provisions discussed infra. Although the facts did not include any settlement, the letter considered what might happen in the case of a settlement. It noted that in that event, there would again be no forfeiture of the exclusivity. Id. at 5 n.6. Moreover, if later filers were unable to initiate a declaratory judgment action, the FDA suggested, "[t]his potential scenario is not one for which the statute currently provides a remedy." Id. At the same time, the letter specifically noted that the particular facts at hand did not raise any allegation of "parked" exclusivity. Id. at 5 n.5. Thus, the FDA had no occasion to address whether the post-MMA regime contains, either as an interpretation of "lawfully maintained" or the forfeiture provisions, a safety valve for removing such a bottleneck.

An analogous argument- that settlement requires conversion from Paragraph IV to Paragraph III-was rejected by the FDA in Letter from Gary Buehler, Dir., Office of Generic Drugs, FDA, to Carmen M. Shepard (Jan. 29, 2008) (interpreting availability of 180-day exclusivity for ramipril). The drug at issue there was subject to the pre-MMA statute, which had a different regime for awarding exclusivity, and did not include the "lawfully maintained" requirement. The FDA did consider whether a settlement results in forfeiture under an MMA provision that applies to pre-MMA ANDAs, but had no occasion to consider the operation of "lawfully maintained." 
tained." Alternatively, a simple statutory change would accomplish that result. ${ }^{92}$

A second doctrinal route to the same end is to provide for forfeiture in the event of settlement. ${ }^{93}$ Under current law, a first applicant loses all eligibility for the bounty if one of several defined events occurs. ${ }^{94}$ One of these pertains to entry-delaying agreements between the brand-name firm and the first applicant. ${ }^{95}$ However, the provision is a mainly cosmetic addition to the forfeiture scheme. Triggering the provision requires a final appellate judgment that the settlement violates antitrust law. That is difficult and time-consuming; by the time the antitrust case is finished - assuming a violation is eventually foundgeneric entry will likely have already occurred, even for settlements with a late entry date. It is doubtful that the provision will ever be triggered..$^{96}$ The antitrust case is a still less likely prospect where the conduct in question is a non-aggression pact that does not include a cash payment. To beef up the forfeiture provision, we propose to simply delete the language that requires an

${ }^{92}$ Adopting our approach to "lawfully maintained," taken alone, might not implement our proposal in all cases. That is because lawful maintenance is determined patent by patent. The brand-name firm might decide to sue on one or more patents, yet strategically refrain from suit on one patent. Settlement as to the litigated patents could result in removal of "lawfully maintained" as to those patents, yet there would still be a lawfully maintained challenge on the unlitigated patent, and so exclusivity would still be available. See Erika Lietzan \& David E. Korn, Issues in the Interpretation of 180-Day Exclusivity, 62 FoOD \& DRUG L.J. 49, 53 n.16 (2007). One way to close this loophole would be an interpretation in which the changed status of the nolonger-litigated patents is extended to the never-litigated patent. Another is to subject these cases to FTC enforcement under Section 5, as discussed infra in note 99 and accompanying text.

${ }^{93}$ For brief, general proposals in this vein, see Protecting Consumer Access to Generic Drugs Act of 2009: Hearing on H.R. 1706 Before the Subcomm. on Commerce, Trade \& Consumer Protection of the H. Comm. on Energy \& Commerce, 111th Cong. (2009) (statement of C. Scott Hemphill); Protecting Consumer Access to Generic Drugs Act of 2007: Hearing on H.R. 1902 Before the Subcomm. on Commerce, Trade \& Consumer Protection of the H. Comm. on Energy \& Commerce, 110th Cong. (2007) (statement of Bernard Sherman, CEO of Apotex, Inc.); Bulow, supra note 61, at 178 ("Welfare would be increased by requiring the forfeiture of any right to 180-day exclusivity by any firm that agrees to a delayed entry settlement."); Alfred B. Engelberg, Eliminating Reverse Payments in Pharmaceutical Patent Challenges 4 (June 6, 2009) (unpublished manuscript) (on file with authors) (similar).

${ }_{94} 21$ U.S.C. $\S 355(j)(5)(D)(i)$. In some cases, patent owners have delisted challenged patents from the Orange Book, raising the possibility that exclusivity might have been forfeited, opening the way to broad generic entry. The D.C. Circuit held that the first filer was entitled to 180-day exclusivity in that circumstance. Teva Pharms. USA, Inc. v. Sebelius, 595 F.3d 1303 (D.C. Cir. 2010).

${ }_{95} 21$ U.S.C. § 355(j)(5)(D)(i)(V). The other forfeiture events are failure to market under certain circumstances, withdrawal of the ANDA, removal of the Paragraph IV certification, failure to receive tentative FDA approval, and expiration of the relevant patents.

96 See Shashank Upadhye, Generic Pharmaceutical Patent and FDA Law $\$ 14.11$ (2010) (arguing that the provision, "while verbose, has no teeth because ... the forfeit will only occur after a ridiculously long period of time"). 
antitrust violation. That would create a forfeiture in the case of any settlement. $^{97}$

A third way to implement this outcome is for the FTC to induce it indirectly in the course of enforcing Section 5 of the FTC Act. The FTC could take the view that if a generic firm settles its suit without the right of immediate entry, yet retains eligibility for the exclusivity, this is a violation of Section 5 . There is ample judicial support for the proposition that manipulation of entry through retained exclusivity is a violation of antitrust law, even in opinions that take a narrow view of antitrust liability in settlement cases. ${ }^{98}$ Even if a settlement with retained exclusivity, thus creating a bottleneck, somehow failed to rise to the level of a Sherman Act violation, the FTC could likely challenge the settlement as a violation of Section 5 of the FTC Act. Manipulating the bounty in this fashion is just the sort of activity that Section 5's extra breadth, relative to the Sherman Act, was made for. The enforcement could be accomplished through FTC challenges in individual cases, or alternatively through rulemaking. An additional benefit of this approach is to reinforce, in certain technical respects, the FDA interpretation of "lawfully maintained" proposed above. ${ }^{99}$

The idea that Section 5 reaches more broadly than other antitrust statutes is controversial. The Supreme Court has stated repeatedly that the FTC Act's prohibitions are broader than those of the Sherman Act. ${ }^{100}$ Thus, behavior that

\footnotetext{
${ }^{97}$ As we note below, however, settlements that permit immediate entry should not forfeit the exclusivity period. Another way to implement the forfeiture is to modify a different forfeiture provision, which gives rise to a forfeiture under certain circumstances in which a generic firm fails to market its drug. 21 U.S.C. $\S 355(\mathrm{j})(5)(\mathrm{D})(\mathrm{i})(\mathrm{I})$. The forfeiture is potentially triggered where a court reaches a final judgment of invalidity or non-infringement, or a settlement to the same effect, and certain other conditions are satisfied. 21 U.S.C. $\$ 355(j)(5)(D)(i)(I)(b b)(A A)$, (BB). That provision could be changed to provide for forfeiture where there is any final judgment. This route would not require the grace period discussed infra because the failure-to-market provisions already contain a grace period.

${ }^{98}$ Cases that emphasize the presence of a bottleneck as a basis for liability include In re Cardizem CD Antitrust Litig., 332 F.3d 896, 907-08 (6th Cir. 2003); Valley Drug Co. v. Geneva Pharms., Inc., 344 F.3d 1295, 1306 n.18 (11th Cir. 2003); King Drug Co. of Florence, Inc. v. Cephalon, Inc., 702 F. Supp. 2d 514, 534, 535-36 (E.D. Pa. 2010). Cases that acknowledge the bottleneck as a basis for liability, while emphasizing the absence of a bottleneck on their particular facts, include In re Ciprofloxacin Hydrochloride Antitrust Litig., 544 F.3d 1323, 1336 (Fed. Cir. 2008); In re Tamoxifen Citrate Antitrust Litig., 466 F.3d 187, 215 (2d Cir. 2006).

${ }^{99}$ As noted supra note 92 , there is a possible loophole in the "lawfully maintained" approach if there are never-litigated patents that are unaffected by a settlement and for which the Paragraph IV certification is still lawfully maintained. In such cases, it will be particularly obvious that the never-litigated patents are being used to manipulate the exclusivity, a recognition that strengthens the case for Section 5 intervention.

${ }^{100}$ See, e.g., FTC v. Ind. Fed'n of Dentists, 476 U.S. 447, 454 (1986) (holding that Section 5 covers "not only practices that violate the Sherman Act and the other antitrust laws but also practices that the Commission determines are against public policy for other reasons" (citations omitted)); FTC v. Brown Shoe Co., 384 U.S. 316, 321 (1966) (holding that Section 5 reaches "practices which conflict with the basic policies" underlying antitrust law, as well as incipient
} 
constitutes unfair competition does not necessarily also violate the Sherman Act's prohibitions of unreasonable restraints of trade or monopolization. Supporting this interpretation are cases like $\mathrm{N}$-Data, where the FTC has read Section 5 to cover conduct that does not clearly violate the Sherman or Clayton Acts. ${ }^{101}$

This conclusion is resisted by some observers, who think it is "no longer tenable" to treat the FTC Act as broader than the Sherman Act. ${ }^{102}$ The argument for equivalence rests upon the proposition that, as Richard Posner puts it, "the Sherman and Clayton Acts have been interpreted so broadly that they no longer contain gaps that a broad interpretation of Section 5 of the FTC Act might be needed to fill." 103

That might once have been true, but it no longer is. To begin, it is worth noting the recent history of antitrust decisions-a history that, almost without exception, makes it harder over time for antitrust plaintiffs to win cases. Judge Easterbrook could speak in 1984 of the asymmetry between false positives and false negatives, ${ }^{104}$ but the antitrust law he was talking about simply doesn't exist anymore. ${ }^{105}$ Courts in the last three decades have dismantled per se prohibitions applied to vertical conduct, ${ }^{106}$ limited per se liability for hori-

violations of antitrust law); FTC v. R.F. Keppel \& Bro., Inc., 291 U.S. 304, 310 (1934) ("It would not have been a difficult feat of draftsmanship to have restricted the operation of the Trade Commission Act to those methods of competition in interstate commerce which are forbidden at common law or which are likely to grow into violations of the Sherman Act ...."); see also FTC v. Sperry \& Hutchinson Co., 405 U.S. 233, 244 (1972) (noting that FTC must "consider[ ] public values beyond simply those enshrined in the letter or encompassed in the spirit of the antitrust laws").

${ }^{101}$ Negotiated Data Solutions LLC, FTC No. 0510094 (Jan. 23, 2008).

102 Richard A. Posner, The Federal Trade Commission: A Retrospective, 72 Antitrust L.J. 761, 766 (2005); see Bruce H. Kobayashi \& Joshua D. Wright, Federalism, Substantive Preemption, and Limits on Antitrust: An Application to Patent Holdup, 5 J. Competition L. \& Econ. 469 (2009).

${ }^{103}$ Posner, supra note 102 , at 766.

${ }^{104}$ See Frank H. Easterbrook, The Limits of Antitrust, 63 Tex. L. Rev. 1 (1984) (proposing a set of threshold filters to minimize false positives, on the grounds that the cost of condemning a beneficial practice is much higher than the harm of allowing an anticompetitive practice to continue).

${ }^{105}$ See, e.g., Peter C. Carstensen, False Positives in Identifying Liability for Exclusionary Conduct: Conceptual Error, Business Reality, and Aspen, 2008 Wis. L. Rev. 295, 295 (2008) (criticizing Verizon Communications Inc. v. Law Offices of Curtis V. Trinko, LLP, 540 U.S. 398 (2004), for its concern about false-positive decisions, and arguing that false negatives are the more serious risk).

106 See Leegin Creative Leather Prods., Inc. v. PSKS, Inc., 551 U.S. 877, 907 (2007) (overruling precedent to hold that the per se rule is inapplicable to vertical agreements to fix minimum resale prices); Ill. Tool Works, Inc. v. Indep. Ink, Inc., 547 U.S. 28, $42-43$ (2006) (requiring proof of market power in patent tying cases); NYNEX Corp. v. Discon, Inc., 525 U.S. 128, 135 (1998) (declining to apply the per se rule to a boycott case involving only a single buyer); State Oil Co. v. Khan, 522 U.S. 3, 18 (1997) (overturning precedent to remove vertical agreements on maximum prices from the scope of the per se rule); Bus. Elecs. Corp. v. Sharp Elecs. Corp., 485 
zontal conduct, ${ }^{107}$ made it harder for plaintiffs to establish conspiracies, ${ }^{108}$ narrowed predatory pricing claims, ${ }^{109}$ and restricted the role of monopolization cases. ${ }^{110}$ Win rates for antitrust plaintiffs in at least one industry hover below 15 percent, ${ }^{111}$ and court rules have made it harder for antitrust plaintiffs to show standing to sue to enforce the laws that remain. ${ }^{112}$

We have no doubt that antitrust at one time was skewed toward over-enforcement, but today if there is any bias it is in the opposite direction. The Supreme Court in the last two decades decided seventeen antitrust cases in a row in favor of defendants. ${ }^{113}$ Only once in the last eighteen years has an

U.S. 717, 735-36 (1988) (holding that the per se rule does not apply to non-price-related forms of vertical agreement).

${ }^{107}$ See Texaco, Inc. v. Dagher, 547 U.S. 1, 5-6 (2006) (determining that a joint venture that set the prices its members would charge was not per se illegal); Nw. Wholesale Stationers, Inc. v. Pac. Stationery \& Printing Co., 472 U.S. 284, 298 (1985) (holding that an act of expulsion from a wholesale cooperative does not fall under the per se rule); NCAA v. of Regents of Univ. of Okla., 468 U.S. 85, 100-01 (1984) (refusing to apply the per se rule to the NCAA's footballtelevising plan because horizontal restraints were necessary for the product to be available at all); Broad. Music, Inc. v. CBS, Inc., 441 U.S. 1, 7 (1979) (holding that the per se rule should not be used when analyzing blanket licenses issued by performing rights organizations).

${ }^{108}$ See Bell Atl. Corp. v. Twombly, 550 U.S. 544, 570 (2007) (imposing a heightened pleading requirement on a plaintiff attempting to use parallel conduct as the initial basis for a claim of anticompetitive conspiracy); Matsushita Elec. Indus. Co., Ltd. v. Zenith Radio Corp., 475 U.S. 574, 595 (1986) (requiring more direct evidence for a conspiracy claim to survive summary judgment, including evidence showing a rational motive to conspire); Monsanto Co. v. SprayRite Serv. Corp., 465 U.S. 752, 764 (1984) (holding that a conspiracy case must be supported by evidence that tends to exclude the possibility of independent action and indicates a conscious commitment to an unlawful common scheme).

${ }^{109}$ Brooke Group Ltd. v. Brown \& Williamson Tobacco Corp., 509 U.S. 209, 222-27 (1993) (requiring proof of below-cost pricing and probability of recoupment in predatory pricing claims); Matsushita, 475 U.S. at 595 (requiring proof of a rational motive to conspire in predatory pricing cases); see also Weyerhaeuser Co. v. Ross-Simmons Hardwood Lumber Co., Inc., 549 U.S. 312, 326 (2007) (holding that the stringent standard for predatory pricing also applies to predatory bidding claims).

${ }^{110}$ See Trinko, 540 U.S. at 405-07 (denying liability for refusal to deal by incumbent telecommunications provider).

${ }^{111}$ See Peter J. Hammer \& William M. Sage, Antitrust, Health Care Quality, and the Courts, 102 Colum. L. Rev. 545, 575 (2002) (concluding that plaintiffs win only 14 percent of antitrust cases in the health care industry). While the health care industry may not be representative, it is one of the largest categories of antitrust claims, and there is a general consensus that plaintiffs today rarely win antitrust suits. But see Daniel A. Crane, Rules Versus Standards in Antitrust Adjudication, 64 WASH. \& LeE L. Rev. 49, 65 (2007) (contending that the rule of reason has become "reinvigorated" in recent years, leading to more wins for plaintiffs).

${ }^{112}$ See Atl. Richfield Co. v. USA Petroleum Co., 495 U.S. 328, 341-45 (1990) (holding that antitrust plaintiffs must prove that their injury resulted from harm to the competitive process); Brunswick Corp. v. Pueblo Bowl-O-Mat, Inc., 429 U.S. 477, 489 (1977) ("Plaintiffs must prove antitrust injury, which is to say injury of the type the antitrust laws were intended to prevent and that flows from that which makes defendants' acts unlawful.").

113 See William Kolasky, Reinvigorating Antitrust Enforcement in the United States: A Proposal, Antitrust, Spring 2008, at 85, 85 (2008) (recording this streak of plaintiff losses). After Kolasky's article was written, the Court extended the streak in Pacific Bell Telephone Co. v. linkLine Communications, 555 U.S. 438 (2009). 
antitrust plaintiff won in the Supreme Court. ${ }^{114}$ We don't intend to suggest that antitrust law is dead; agencies continue to prosecute cartels and private parties continue to file antitrust cases. But to suggest that as they are currently interpreted the Sherman and Clayton Act cover everything that might possibly be anticompetitive flies in the face of the realities of modern antitrust.

Nonequivalence, in short, has its uses. That is particularly true if the prospect of treble damages leads courts to constrict the scope of liability in private plaintiff cases. Even if it is appropriate for courts to limit liability to compensate for the heightened false-positive risk created by treble damages, ${ }^{115}$ it does not follow that the FTC must adhere to the same path. The FTC seeks injunctive relief, not treble damages. That difference reduces concerns about false positives and overdeterrence. Put another way, the FTC's optimal scope of liability may well be broader than the courts'. Nonequivalence allows the FTC to take advantage of that difference, while the Sherman Act applies a harsher penalty to a narrower class of activity. ${ }^{116}$

What if the parties settle in a manner that permits immediate entry? In that rare case, we would grant exclusivity, largely consistent with the successful defense requirement, ${ }^{117}$ because the generic firm has in substance won the case. To implement this difference, we would add a short grace period after settlement-sixty days, say-before the "lawfully maintains" or forfeiture provision took effect, so that generic firms entering settlements that did not delay entry could still receive the bounty.

A difficult question with earned exclusivity is whether to grant exclusivity to drug makers that file a Paragraph IV certification but are never sued and

114 Am. Needle, Inc. v. Nat'l Football League, 130 S. Ct. 2201 (2010).

115 This is controversial. See Robert H. Lande, Are Antitrust "Treble" Damages Really Single Damages?, 54 Oніо Sт. L.J. 115 (1993).

116 For an argument along similar lines, see Thomas C. Arthur, A Workable Rule of Reason: A Less Ambitious Antitrust Role for the Federal Courts, 68 AnTitrust L.J. 337, 384-85 n.285 (2000) ("While the FTC cannot afford compensation to the private parties favored by non-Chicagoans, it may be more likely than the current federal judiciary to prohibit the practices that concern Chicago's critics.”).

117 The FDA's very first award of exclusivity, involving Maxzide, was based on a settlement in which the brand-name firm acknowledged noninfringement. A district court affirmed the FDA's interpretation that such a settlement sufficed for an award of exclusivity. See Transcript of Proceedings at 5-6, 11-12, Barr Labs., Inc. v. Bowen, No. 87-4574 (D.N.J. Nov. 20, 1987). The FDA took the view that settlements in which a district court found the patent invalid or not infringed qualified for an award, but a patent license did not. 1988 FDA Guidance, supra note 84, at 3-4; see also Abbreviated New Drug Application Regulations, Proposed Rule 54 Fed. Reg. 28,872, 28,895 (July 10, 1989) (“[F]inal adjudication on the merits is not required to trigger the 180-day period."). In our proposal, settlements that permit immediate entry would receive exclusivity even if there is no concession of invalidity or noninfringement. This difference from the FDA is consonant with our different approach to cases without litigation, which, like patent licenses, permit immediate entry for one generic firm without opening the way for all other entrants. 
therefore can enter upon FDA approval. ${ }^{118}$ As noted above, this is a significant category of cases, amounting to nearly half of all exclusivity approvals over the past four years. ${ }^{119}$ There is an argument that the generic firm may not have earned its exclusivity in this case. That was the position taken by the FDA in adopting a successful defense requirement. ${ }^{120}$ Moreover, as discussed in the next Part, in at least some cases the generic would have filed the ANDA anyway, even without the exclusivity. Generics already have an incentive to file quickly, because the first filer will also tend to have first approval, with a significant and valuable headstart in signing up customers.

On the other hand, the ANDA filer subjected itself to the risk of suit. The generic firm's actions are not trivial: aside from developing its bioequivalence package, it has developed a detailed explanation, as it is required to do, of why the patent is invalid or not infringed. ${ }^{121}$ It may have raced to file, with the benefits discussed in the next Part. ${ }^{122}$ And it may have made the ANDA investment decision before it knew whether it would face a long, expensive, and uncertain suit or just a straightforward bioequivalence analysis. Just as we grant patents not only to those who face a long road, but to those who happen upon an invention easily, we might grant generic exclusivity both to those who turned out to have to work hard for generic entry and those for whom it turned out to be easy. ${ }^{123}$ The D.C. Circuit has adopted this view in a related context, holding that where the patentee delists a challenged patent from the Orange Book the first filer to have challenged that patent is entitled to 180day exclusivity. ${ }^{124}$ While the issue is not free from doubt, we think that an

118 FDA approval is not immediate; the review process can take several years, even if there is no patent issue. Moreover, if a Paragraph IV certification is filed as to some but not all unexpired patents, FDA approval is delayed until expiration of the unchallenged patents.

119 See supra Part I.C.

120 "To apply the section [granting exclusivity] where there has been no lawsuit would require that the agency . . . assume that Congress intended, contrary to the goals it stated in the legislative history, to create an incentive for delay in generic competition, without any countervailing benefit to society. Moreover, it would provide a windfall to an applicant who has not devoted the considerable time and money necessary for patent litigation." Abbreviated New Drug Application Regulations; Patent and Exclusivity Provisions, Final Rule, 59 Fed. Reg. 50,338, 50,353 (Oct. 4, 1994).

${ }^{121}$ See 21 U.S.C. $\S 355(j)(2)(B)(i v)(I I)$ (requiring a "detailed statement of the factual and legal basis" for the Paragraph IV certification).

122 See Legislative and Regulatory Responses to the FTC Study on Barriers to Entry in the Pharmaceutical Marketplace: Hearing Before the S. Comm. on the Judiciary, 108th Cong. (2003) (statement of Timothy J. Muris, Chairman, Fed. Trade Comm'n) (favoring exclusivity for such firms on the ground that it gives generic firms "an incentive to go ahead and be clever and innovative").

123 The same is not true of those generic firms that settle rather than resolve a challenge. The question of whether the patentee will file a suit is not in the generic firm's control, so the generic cannot eliminate that uncertainty. Settlement decisions, by contrast, are something the generic firm can control and therefore can plan for.

124 Teva Pharms. USA, Inc. v. Sebelius, 595 F.3d 1303, 1318 (D.C. Cir. 2010). 
award of exclusivity where there is a challenge but no suit is a reasonable approach. ${ }^{125}$

In some cases, though, the generic firms may in fact know (or at least strongly suspect) that the patentee will not file suit in response to a Paragraph IV challenge, perhaps because it is clear that the patent does not cover the proposed drug product. Certainly that turns out to be the case in a surprisingly large number of Paragraph IV filings. We need to encourage such filings only if the generic expects ex ante to face significant expenditure or uncertainty to enter the market. That is not true in cases of settlement; it might or might not be true in cases where no suit is ever filed. ${ }^{126}$ Certainly generics that launch at risk are making an assessment of the likelihood of a successful suit.

\section{LITIGATION IN AN EARNED EXCLUSIVITY WORLD}

What would litigation and settlement incentives look like in a world where generic entrants must earn their 180-day exclusivity? We foresee several effects, most positive but some arguably negative.

\section{A. Taking Cases to Judgment}

First, earned exclusivity will reduce the prevalence of anticompetitive settlements in which the patentee pays the generic to stay out of the market. Exclusion payments work because the patentee stands to lose more from the invalidation of its patent than the generic challenger stands to gain. This follows from the higher price patent owners charge during the period of brand exclusivity. As discussed above, once generic companies enter the market, the average price falls dramatically, with drug purchasers capturing the remaining value. The fact that the generic can settle the case and still obtain 180 days of exclusivity expands the range of settlements that are win-win for the litigating parties, even though they are costly to the public as a whole. If settling the case means that the generic has to give up its 180-day exclusivity-and hence a substantial percentage of its expected profits-fewer generics are likely to settle, at least on the same terms. And while some patentees may simply pay the generic more to compensate for the loss of exclusivity, ${ }^{127}$ in equilibrium the narrowed range of feasible settlements means that fewer cases will settle.

125 This result is obtained under any of the doctrinal routes discussed above. That is, the Paragraph IV certification remains "lawfully maintained," and because there is no settlement, the statutory and FTC routes would have no effect on the availability of exclusivity. An alternative approach would be to grant a lesser period of exclusivity, say ninety days, to generics whose ANDA is approved without the need for litigation.

${ }^{126} \mathrm{We}$ would also grant exclusivity if a drug maker launches at risk, but that is unlikely to matter much in practice. The launch triggers the exclusivity period immediately, and later-filing generic firms are seldom ready to launch by the time the exclusivity period expires.

${ }^{127}$ Or perhaps not. Settlement without blocking is less valuable to the brand-name firm, causing payments to tend to fall. Which effect predominates is uncertain. 
The same is even more likely true of what we have described as non-aggression pacts. Parties that today settle without payment are basing the entry date on the relative value of exclusivity to both parties. Because the generic can obtain 180 days of exclusivity by settling, and because that exclusivity accounts for a majority of the revenue they receive in many cases, they are willing to delay entry substantially in exchange for keeping their exclusivity. If they have to earn exclusivity, that kind of delayed-entry settlement will mostly disappear, replaced with cases litigated to judgment or perhaps with settlements that permit immediate entry.

In this context, litigating more cases to judgment is desirable. As noted above, both the Supreme Court and commentators have observed that the invalidation of patents is a public good: one party bears the costs of invalidation, but lots of others share in the benefits. ${ }^{128}$ And like most public goods, the invalidation of patents is likely to be undersupplied. Generic manufacturers that have evidence invalidating a patent are using that evidence to obtain a private sweetheart deal, rather than to benefit the world at large by invalidating the patent. ${ }^{129}$ Under earned exclusivity, some-though not all-of those patents will be invalidated. That invalidation provides a substantial social benefit. ${ }^{130}$

Of course, generic firms won't win all the cases that are litigated to judgment rather than settled under earned exclusivity. Sometimes the patent will be held valid and infringed. In that case, the public will continue to have to pay the monopoly price for the drug until the patent expires. But that is as it should be. If the patent is valid and infringed, the patentee should be able to exclude others and command a supracompetitive royalty; that's the benefit of the patent bargain. And the heightened certainty the decision will bring to other litigants is itself of social value.

In any event, the cost to the public is unlikely to be that great. First, data suggest that pharmaceutical patent owners win only about half of the cases that go to judgment now, ${ }^{131}$ and presumably would win even fewer of the ones

128 See sources cited supra note 22.

${ }^{129}$ As noted supra, we would ban such sweetheart deals, both cash deals and non-aggression pacts that manipulate the exclusivity; we think they quite clearly violate the antitrust laws. HovenKamp et Al., supra note 54, § 15.3a1[C]; Hemphill, Paying for Delay, supra note 61; Hovenkamp et al., supra note 8 . The courts have not so far been receptive to this argument (at least in the case of cash deals, see sources cited supra note 70), and we assume in this article that that trend will continue.

${ }^{130}$ While we discuss invalidity here, the same logic applies to a finding of noninfringement. A generic that succeeds in designing around a patent while making a bioequivalent drug has provided a public benefit, too.

${ }^{131}$ RBC Capital Markets, Pharmaceuticals: Analyzing Litigation Success Rates (Jan. 15, 2010) (concluding that generic firms won 48 percent of cases that reached judgment between 2000 and 2009). 
that defendants didn't settle under an earned exclusivity regime. ${ }^{132}$ The patent owner win rate is substantially higher than in the previous decade, when brand-name firms won only 27 percent of cases that went to judgment. ${ }^{133}$ The drop in the generic win rate is likely traceable to two changes we think occurred in challenge and settlement practice. The first is an increase in settlements in weak-patent cases after the FDA's earned-exclusivity rule was rejected, a change that would further strengthen our view that those settlements are problematic. The second is an increase in the filing of weak generic claims, motivated in part by the prospect of a future settlement payoff. Such claims, as we noted above, bring little consumer benefit.

Second, the fact that the patentee is paying the defendant a substantial amount to stay out of the market suggests that the parties think there is a significant chance the defendant will win; a patentee confident of victory would not be willing to pay as much to end the challenge. ${ }^{134}$ Finally, if the patentee pays the defendant to stay off the market altogether, the patent may as well be valid from the public's perspective; they won't benefit from generic entry regardless. Settlements that pay a generic to delay entry but still allow entry before expiration give the public some benefit, but less than they would expect from litigation. ${ }^{135}$ Some of the benefit, moreover, is an illusion, because entry is timed to coincide with a product switch. By the time entry has occurred, much or most of the sales may have migrated to the newer product not yet subject to generic entry. ${ }^{136}$ And while other generic entrants might eventually invalidate the patent, they both have less incentive and, as discussed above, less ability to do so, ${ }^{137}$ and will likely be able to do so only later in the patent term.

\footnotetext{
${ }^{132}$ Settlements that would not happen without retained exclusivity are likely to be disproportionately cases that the generic firm was likely to win absent the settlement. That is because the gain from entry-delaying settlement is so much higher (and hence settlement more likely) when the patent protection is weak and the brand-name firm has more to lose in litigation. Removing this tool of settlement would likely have a disproportionate effect on strong generic challenges.

133 See Fed. Trade Comm'n, Generic Drug Entry, supra note 31, at vi (studying results through June 2002).

${ }^{134}$ To be sure, all litigation is uncertain, so smaller payments may reflect a high but not total degree of confidence that the patentee will win the lawsuit.

135 This follows from the fact that the patentee had to pay the defendant to agree to the delayed entry; the function that payment serves is to move the entry date back from what the parties would otherwise have agreed to.

${ }^{136}$ For example, in the case of Provigil, scheduled entry under the settlements was timed to occur after Cephalon switched patients to Nuvigil, a single-enantiomer version of the drug. See Complaint at 23-24, FTC v. Cephalon, Inc., 551 F. Supp. 2d 21 (D.D.C. 2008) (No. 08-244) (making this argument, and asserting further that Cephalon delayed Nuvigil launch to coincide more closely with generic entry on Provigil). For an analysis of the combination of settlements and product switches, see Carrier, supra note 66.

${ }^{137}$ See supra text accompanying notes 63-64.
} 
Finally, while there are some additional litigation costs that will be incurred as more cases move further towards trial or judgment, those litigation costs are dwarfed by the magnitude of the stakes at issue in these cases. Settling a pharmaceutical patent case might plausibly save each side at most a few million dollars in legal fees; in many cases the settlement occurs so late in the case that the savings are trivial. ${ }^{138}$ But even assuming a high end number, the savings from settling all the cases in our database are far outweighed by the cost to consumers of a single year without competition in a single blockbuster drug.

\section{B. EArlier Competitive Entry}

Second, an earned exclusivity requirement accelerates the competitive effects of entry even in cases in which the patentee and the first generic entrant do settle. As we said earlier, generic entry results in a sharp drop in the price of a drug, but 180-day exclusivity moderates that effect. Data on drug prices shows that the average price drops only slightly when an exclusive generic firm enters, creating a duopoly. ${ }^{139}$ The generic product is usually priced at only a slight discount to the branded product during this period. ${ }^{140}$ When 180 day exclusivity expires and other generics enter, the generic price drops quite substantially, often to 20 percent or less of the original patent owner's price. Thus, consumers benefit somewhat from first generic entry, but they benefit more from subsequent entry by other generic firms.

An earned exclusivity requirement deprives the first generic drug maker of 180-day exclusivity if it settles the case with delay rather than winning it. As a result, under our proposal even with an exclusion payment consumers will benefit from lower prices earlier than they do today. The settling generic firm will no longer be able to serve as a bottleneck to the entry of other generic firms.

\footnotetext{
${ }^{138}$ See, e.g., Press Release, Glaxo Wellcome PLC, Glaxo Wellcome PLC Re Genpharm Litigation (Oct. 23, 1995) (reporting settlement of litigation over Zantac on the eve of trial); Ranbaxy and GlaxoSmithKline Enter into an Agreement to Settle Valacyclovir U.S. Patent Litigation, Bıттесн Wк., Aug. 8, 2007, at 853 (same, as to Valtrex); Meda Settles Patent Litigation with Apotex, FDA News, Apr. 29, 2008 (same, as to Astelin); King, Aventis, Cobalt Agree to Dismiss Patent Litigation Regarding ACE Inhibitor Altace, Heart Disease WrLy., Apr. 9, 2006, at 233 (reporting settlement as to Altace during trial); James DeGuilio, Impax Settles Amrix Patent Suit with Cephalon, Patent Docs (Oct. 14, 2010) (same, as to Amrix), http://www.patentdocs.org/ 2010/10/biotechpharma-docket-2.html.

139 See supra notes 27-29 and accompanying text.

${ }^{140}$ In some cases, this measure actually overstates the competitive benefit of the first generic entrant. For example, the generic firm might nominally enter, but agree to pay a high royalty rate to the brand-name firm, which in turn induces a high generic price, or accept a quantity cap. Such entry is not much different from a market structure in which the brand-name firm is the sole seller. The absence of a bottleneck promotes competition in this situation as well.
} 


\section{Effects on Incentives to Bring Patent Challenges}

The previous two effects of our proposal are unambiguously positive. The biggest risk of earned exclusivity is that it will discourage generic firms from challenging patents, leaving weak patents intact. If this happened in a significant number of cases, it could hurt rather than help the public by leading to fewer invalidations and fewer instances of early entry. In this section, we consider some possible effects of our rule on the incentive to bring a challenge.

We think it likely that earned exclusivity will deter some generic challenges that occur today. Like agricultural subsidies that pay farmers not to grow crops, exclusion payments have conditioned some generic firms to automatically challenge at least one patent on a sufficiently valuable drug, ${ }^{141}$ hoping that they can be paid to go away. Generic firms that file for that purpose may still do so under our scheme, but because settlements are less likely under our proposal, so too will be challenges designed to provoke exclusion-payment settlements.

But so what? Generic challenges are not an end in themselves. We want to encourage them only to the extent they will benefit the public, by invalidating or limiting the scope of bad patents and allowing earlier competition for the corresponding drugs. A generic that files a challenge only in order to be paid to drop that challenge is not providing such a benefit; nor is a generic that files a challenge destined to fail. We shouldn't worry about weak generic challenges because they are unlikely to lead to the invalidation of a patent and hence to early generic entry.

The right question is whether generic companies will be less likely to file challenges that actually lead to early entry if they cannot obtain 180-day exclusivity by settling with the patent owner. For that to be true, the number of challenges must decline so far as to overwhelm the fact that under an earned exclusivity regime more of the challenges that are filed will go to judgment or be settled on more procompetitive terms.

This is ultimately an empirical question, one we cannot answer definitively without trying our alternative. We might obtain some evidence from the recent practice by pharmaceutical patent owners of authorizing generics to compete with ANDA challengers during the 180-day period. ${ }^{142}$ That practice, by adding an additional generic competitor into the market, reduces the profit-

${ }^{141}$ For the most valuable drugs, almost all of them attract a patent challenge. See Hemphill \& Sampat, supra note 18.

${ }^{142}$ The 180-day exclusivity period only applies to other ANDA filers seeking entry by means of Paragraph IV certifications. It does not prohibit the brand-name firm from licensing another competing generic firm. Teva Pharm. Indus. Ltd. v. Crawford, 410 F.3d 51, 53-55 (D.C. Cir. 2005). 
ability of a successful challenge and hence, at least in theory, the incentive to launch a challenge in the first place. Authorized generics likely reduce the incentive to challenge significantly more than an earned exclusivity scheme would, since generic challengers may see their profitability cut by half or more, compared to successful entry without an authorized generic competitor. Nonetheless, the effect of authorized generics on ANDA challenges can put a sort of upper bound on the risk of reducing generic challenges. If generics are not shying away from filing Paragraph IV ANDAs against firms that use authorized generics, it suggests they are overcompensated, relative to the minimum needed to induce a challenge. And a recent empirical study concludes that authorized generics have not impeded the flow of ANDA filings. ${ }^{143}$

In the absence of direct empirical evidence, several factors will drive the likely effect on generic challenges. The first is the size of the market. Hemphill and Sampat find that the more money is at stake for a particular drug, the more likely one or more generics are to file an ANDA challenge to the patents covering that drug. And for many large drugs, multiple generic firms file challenges, often on the same day (the first day the law permits them to do so). ${ }^{144}$ In addition, our survey found that nearly half of the 180-day awards (including twelve of twenty-three no-suit awards, and five of nine settlement awards) occurred in circumstances in which there was at least one, and often many, other generic challengers waiting in line behind the first generic filer. This, too, suggests there is already an overabundance of incentives to challenge the largest drugs, even without the 180-day exclusivity period.

The real risk of discouraging challenge is for the smallest drugs, the ones for which the value of 180-day exclusivity is not high enough to cover the anticipated costs of a challenge. But because of the smaller market for those drugs, the social value of generic entry into those markets is correspondingly smaller. That is not to say the social cost of discouraging challenges to these smaller drugs is zero, but the absence of real risk of lost challenges to big drugs reduces the possible social cost overall.

\footnotetext{
${ }^{143}$ The study, sponsored by PhRMA, concludes, "During the recent five-year period of increases in authorized generics, we find little overall change in the number of drugs facing $[P]$ aragraph IV certifications, the total number of [P] aragraph IV certifications filed, or the timing of [P] aragraph IV certifications relative to new chemical entity (NCE) approvals." Ernst R. Berndt, Richard Mortimer \& Andrew Parece, Do Authorized Generic Drugs Deter Paragraph IV Certifications? Recent Evidence 1 (Analysis Group Working Paper, 2007), http://www.analysis group.com/uploadedFiles/Publishing/Articles/PhRMA_Authorized_Generic_Entry.pdf.

${ }^{144}$ In the case of new chemical entities (drugs that contain no active ingredient previously approved by the FDA), generic challengers must wait to submit an ANDA with a Paragraph IV certification until four years after the brand-name approval. 21 U.S.C. § 355(j)(5)(F)(ii). That delay increases the probability that multiple generic firms will be ready to file on the first day possible.
} 
The second factor is the quality of the challenge that is likely to be deterred. Strong challenges benefit society directly when they lead to early generic entry and indirectly by discouraging brand-name drug makers from applying for patents that are unlikely to be judged valid and infringed. Challenges that are unlikely to be successful, by contrast, just cost money and create uncertainty. So if a challenge is unlikely to succeed, we worry less about deterring it. If a challenge was likely to result in settlement that delayed entry, often until just before the patent was to expire, we worry less about deterring that challenge, because the social benefit of that delayed entry is less. And it is those generic challengers who expect to settle who are most likely to be deterred by an earned exclusivity rule.

Even more dramatic, our study finds that 23 out of 49 (47 percent) instances of 180-day exclusivity occurred because the patentee chose not to file a suit against the ANDA at all. In each of those cases, the generic did relatively little to justify the exclusivity. Had the FDA not granted exclusivity, the mere act of filing an ANDA in those cases would have opened the market. We concluded above that generics should still get exclusivity in those circumstances, but the fact that they have a decent chance at getting that exclusivity without having to litigate means that they are unlikely to forgo challenges that have even a moderate chance of success.

Third, the timing of challenges also matters. Only the first ANDA filer is entitled to 180-day exclusivity; a generic that files one day later gets no such exclusivity, even if they are the ones to invalidate a patent. Because there is a significant advantage to being the first generic challenger, we also need to think about whether the discouraged challenge would have displaced a higherquality challenge. For new chemical entities (NCEs), patentees get four years of data exclusivity before generic challengers may file an ANDA with a Paragraph IV certification. ${ }^{145}$ As a result, several generics commonly file an ANDA on the same day - the first day after data exclusivity expires. But for non-NCE drugs, the desirability of being first results in a race to file the first ANDA with a Paragraph IV certification on an Orange Book-listed patent.

A generic that rushes to file an ANDA without doing its research may actually have a weaker case than one that waits. For example, an early generic entrant may rush onto the market by copying the patentee's product exactly, relying only on the possibility of invalidating the patent or on long-shot claims like inequitable conduct. By contrast, a generic firm that spends the

\footnotetext{
${ }^{145} I d$. Data exclusivity provides a measure of protection to drug innovators with little or no patent coverage. For analyses, see, e.g., Rebecca S. Eisenberg, The Role of the FDA in Innovation Policy, 13 Мich. Telecomm. \& Teсн. L. Rev. 345, 359-64 (2007); Hemphill, Paying for Delay, supra note 61, at 1607-10; Benjamin N. Roin, Unpatentable Drugs and the Standards of Patentability, 87 Tex. L. Rev. 503, 565-67 (2009).
} 
time to design around the patentee's drug, coming up with a bioequivalent drug that may not infringe the patent, may take longer to do so, but may also bring a stronger challenge. If earned exclusivity discourages the long-shot challenge because the challenger was simply hoping for a settlement, the result may be to give the second challenger-the one with a stronger casemore incentive to bring its challenge.

We believe the relationship between speed and quality is generally inverse. But the relationship is not perfect. As a result, earned exclusivity is not a perfect solution to the race problem. But even if earned exclusivity is deterring some challenges, if it deters weaker, long-shot challenges it may actually make it easier to bring stronger challenges.

Finally, some generic firms may file challenges as a sort of fishing expedition, hoping to find information in the course of discovery that suggests the patent was invalid (or fraudulently obtained). Settlement could conceivably encourage these fishing expedition challenges, by giving the generic challenger an "out" if the fishing for invalidity is not successful. ${ }^{146}$ As a result, an earned exclusivity rule might discourage some fishing expedition challenges because it reduces the ex ante expected value of those challenges.

It's not clear whether we should think of this as a good thing or a bad thing. Fishing expeditions are probably weaker than other sorts of challenges. So it is not clear that we should be much bothered by a rule that discourages them. But precisely because the likely outcome of these sorts of challenges is uncertain, some of the discouraged fishing expeditions would have been successful, resulting in invalidation of the patent. And for certain types of challengesinvalidity based on incorrect inventorship, for example, or unenforceability based on the concealment of prior art from the PTO-a fishing expedition may be the only way to uncover problems with the patent.

There is therefore some risk that generic firms will be less likely to bring some sorts of ANDA challenges. But the risk is surprisingly modest. Most of the challenges that will be discouraged are weak or speculative ones, and there is even some reason to believe that an earned exclusivity rule may encourage stronger rather than weaker challenges. We think that while there is some potential social loss here, it is outweighed by the benefits discussed above.

\footnotetext{
146 While the generic challenge in that case would by definition be weak, there is always some uncertainty associated with litigation, and so the generic firm might expect to get paid some (small) amount to drop its challenge.
} 


\section{ALTERNATIVE STATUTORY CHANGES}

Earned exclusivity is not the only way to reduce the scope for manipulation of the 180-day period. Here we consider three statutory alternatives that have been proposed. Each is superior to the status quo but has significant drawbacks that are avoided by earned exclusivity. Moreover, each would require congressional action, whereas earned exclusivity can be implemented through agency action.

\section{A. Tying Exclusivity to Suit}

First, Congress could reduce manipulation by reducing the effect of the 180-day period on later filers. As discussed above, in some cases the later filer is never sued, and it becomes a time-consuming, uncertain, and costly process to file a declaratory judgment suit and thereby, eventually, cause a forfeiture that opens the way for entry by the later filer. The statute could be altered so that if a later filer is never sued and is otherwise ready for approval (as indicated by an FDA grant of "tentative approval"), FDA approval will not be blocked by the first filer's exclusivity period. There are several distinct statutory changes that would accomplish this result. ${ }^{147}$

This method would limit manipulation and promote rapid entry in the case where the later filer is never sued. It would change nothing, however, where the later filer is sued by the brand-name firm and FDA approval is blocked by the first filer's 180-day period. In that case, the bottleneck persists. It is likely, moreover, that this limitation would increase in importance after the statutory change, as the brand-name firm altered its strategy in response. For example, the brand-name firm might simply go ahead and sue the later filer, then proceed slowly with the suit, in which case the generic firm remains subject to the bottleneck. As a result, we think our proposal solves a broader problem than is addressed by this approach.

\footnotetext{
${ }^{147}$ One option would be to reduce the set of ANDAs that are delayed by the exclusivity period. At present, the 180-day period blocks only those ANDAs with Paragraph IV certifications. It could be narrowed further, so that the 180-day period blocks only those ANDAs with Paragraph IV certifications in which the later filer is actually sued. Another option is to expand forfeiture, so that an ANDA filer otherwise eligible for approval triggers a forfeiture. The difference is that forfeiture would pave the way for entry of all later filers, not just the ANDA filer who was never sued. For proposals along these lines, see H.R. 1706, 111th Cong. $§ 4$ (2009) (proposing new triggering event for failure-to-market forfeiture provision, if later filer's suit dismissed for lack of subject matter jurisdiction or where filer receives covenant not to sue); H.R. 1902, 110th Cong. $\S 4$ (2007) (same); Ashlee B. Mehl, Note, The Hatch-Waxman Act and Market Exclusivity for Generic Drug Manufacturers: An Entitlement or an Incentive, 81 ChI.-Kent L. Rev. 649, 672-77 (2006).
} 


\section{B. First-Entry Exclusivity}

A second strategy is for Congress to grant exclusivity not to the first ANDA filer, but to the first generic to successfully enter the market. ${ }^{148}$ This approach differs from earned exclusivity in that it would give exclusivity to the first generic to win the lawsuit, secure approval under an attractive settlement, or secure approval having never been sued-whether or not that generic was the first ANDA filer.

Like earned exclusivity, first-entry exclusivity reduces manipulation of the 180-day period. It rewards generic firms that choose to gamble on quick litigation rather than accept delayed entry under settlement, thereby encouraging the former at the expense of the latter. Moreover, even if the first challenge fails, others can still step in, encouraged by the continued possibility of the 180-day period. ${ }^{149}$ Even if litigation does not occur in equilibrium, the generic firms would have a beneficial incentive to compete to reach the earliest entry date. Moreover, first-entry exclusivity might seem to have a significant benefit over earned exclusivity, by replacing the race to file-and the problem of quick but weak challenges-with a race to enter.

A first-entry exclusivity regime, however, has a severe drawback: it greatly reduces the incentive to invest in an early, high-quality challenge. The challenger is at risk of losing exclusivity to another generic firm, through no fault of its own, simply because the other firm's suit happens to reach judgment faster. And if that risk does not exist, because the challengers are all in the same case (whether all sued at the same time, or later consolidated), the problem is potentially worse. For in that case, if the challenger wins the litigation, other generic firms do too, and at the same time. ${ }^{150}$ Multiple challengers then share in the exclusivity, with low profits for each firm. ${ }^{151}$

A first-entry regime also creates a strong incentive to free ride. A generic firm can observe a challenge-either the fact of a Paragraph IV certification, or the resulting litigation-initiated by another firm on a particular drug, and then file its own challenge. For many drugs, this information is valuable. Another firm might not have realized the profitability of the challenge, or how to achieve it. Under earned exclusivity, that incentive is preserved because a later filer is not eligible for a large reward, and can divest the first filer's

\footnotetext{
${ }^{148}$ For a proposal in this vein, see Sherman, Statement at H.R. 1706 Hearing, supra note 67.

${ }^{149}$ Not entirely, however, because a first loss by a generic will make it harder as a practical matter for a second generic to win its challenge, even if that challenge is objectively better. firm.

${ }^{150}$ Not always; some noninfringement strategies, for example, might be unique to a single

${ }^{151}$ In general, the generic firm would prefer a $1 / n$ chance of sole exclusivity, compared to sharing exclusivity as one of $n$ entrants because prices and profits are lower in the latter case.
} 
exclusivity only with great difficulty. Under a first-entry regime, the incentive to identify and invest in high-quality challenges is comparatively small.

Generic incentives are even worse once the likely responses of the brandname firm are considered. For example, the brand-name firm can remove the incentive to litigate rather than settle, by granting the settling generic firm a license to enter as an authorized generic when (and if) the litigating generic firm wins its case. ${ }^{152}$ The brand-name firm can also game the system by authorizing a particular generic firm's entry, and thus grant the 180-day period, to one firm at the expense of another. This would be valuable if the favored generic firm is a slow or ineffective entrant, or to punish or deter challenges from disfavored generic entrants. Or it could sue multiple generics in the same lawsuit, so that any resulting outcome would apply to all of them at the same time. ${ }^{153}$

\section{Shared Exclusivity}

A third statutory alternative is a mixture of the status quo and first-entry exclusivity. Under this proposal, both the first filer and a successful later filer would share in the 180-day period. ${ }^{154}$ This proposal has some of the same problems as first-entry exclusivity. It would reduce the incentive to invest in high-quality challenges, given the risk of unexpected loss, the prospect of sharing with other, multiple "first winners," and the likelihood of free riding. It would also be subject to the same sort of gaming by the brand-name firm.

Shared exclusivity is inferior to pure first-entry exclusivity in a significant respect. Under shared exclusivity (as with tying exclusivity to suit, and in contrast to earned exclusivity), a first filer retains exclusivity even if it settles. ${ }^{155}$ This is not a problem for a later filer that is never sued; under shared exclusivity, such a firm is treated as a "first applicant," receives approval

152 This is already an element of current settlement practice, as generics settle on the understanding that they will be allowed to launch on an accelerated basis if any other generic firm secures FDA approval. See, e.g., King Drug Co. of Florence, Inc. v. Cephalon, Inc., 702 F. Supp. 2d 514, 532-33 (E.D. Pa. 2010) (noting such clauses in settlements between Cephalon and four generic firms).

${ }^{153}$ Like low-priced authorized generics, this is a strategy, like predatory pricing, which requires the brand owner to sacrifice short-term profits in hopes of discouraging generic entry. In any given case, the patent owner would be better off facing only a single generic for the first 180 days, since that generic will charge a higher price and therefore likely take fewer sales away from the brand. But the advantages of discouraging generic challenge across all drugs may outweigh that short-term benefit.

${ }^{154}$ See, e.g., S. 1315, 111th Cong. (2009). This proposal was advanced in Sherman, Statement at H.R. 1706 Hearing, supra note 67. For an academic analysis advocating this approach, see Carrier, Solving the Drug Settlement Problem: The Legislative Approach, supra note 66.

155 If the first filer in fact invalidates the patent, providing a path for other generics to enter the market, it would make no sense to share that exclusivity with another. So shared exclusivity of necessity must involve cases in which the first filer did not win a patent case. 
without delay, and shares in the 180-day period. The problem arises for later filers that are sued, and whose ANDA would receive approval but for the bottleneck. That would be the case, for example, if the automatic stay expired but the district court had not yet ruled. For these would-be entrants, shared exclusivity is no help until the district court decides the case.

Aside from these differences, an earned exclusivity proposal is easier to implement than any of these alternatives. Legislative change is not an easy task. Statutory surgery, particularly in a field as complicated as drug regulation, carries a significant risk of unintended consequences. Indeed, when the Hatch-Waxman amendments were negotiated in 1984, the 180-day bounty was seen as a relatively unimportant provision, the future effects of which were unanticipated. ${ }^{156}$ More important, there is some risk that any legislative proposal in this area might be hijacked by drug makers. For example, when the statute was amended in 2003, the FTC's proposals to address the pay-fordelay settlement problem were watered down and altered. In some respects, the 2003 statutory changes actually worsened the problem of delayed generic entry. ${ }^{157}$ Thus, a proposal that can be accomplished through agency action, such as ours, has practical advantages over an alternative that requires a statutory change. Nonetheless, first-entry exclusivity (including the shared exclusivity variant) is broadly consistent with earned exclusivity, and is certainly an improvement on the present system.

\section{CONCLUSION}

In this article, we have focused on drugs that are subject to the 2003 statutory amendments to the Hatch-Waxman regime. That is where the most good can be done: the set of "pre-2003" drugs is dwindling, and the current regime can be perfected without resorting to statutory change. But, to a first approximation, the bottleneck problem is the same: for both kinds of drugs, later filers are delayed by retained exclusivity. In fact, pre-2003 drugs are the origi-

\footnotetext{
${ }^{156}$ See, e.g., James C. Morrison, Update on the Waxman-Hatch Amendment Implementation, 43 Food Drug \& Cosmetic L.J. 553, 554 (1988) (article by FDA official describing an early controversy involving the exclusivity period, and noting that "[t]his section has not been highlighted in any speeches or guidance letters because the agency did not expect it to be of much significance").

${ }^{157}$ See supra notes 63-64 and accompanying text (explaining that forfeiture does not occur until after an appeal).
} 
nal source of our concern; ${ }^{158}$ our goal is to neutralize this problem as it might arise in the current regime. ${ }^{159}$

The point of giving generic firms 180-day exclusivity is to encourage them to challenge weak patents and enter the market earlier, lowering prices and benefiting consumers. But 180-day exclusivity has been hijacked. Today, it is a tool that encourages weak challenges to patents in the hopes of prompting settlement, and leads generic firms to settle even strong challenges for delayed entry in exchange for keeping their exclusivity. Consumers are arguably worse off than they would be with no 180-day exclusivity at all. The system can be dramatically improved by a simple rule: Want to get paid a bounty? Earn it.

${ }^{158}$ See, e.g., King Drug Co. of Florence, Inc. v. Cephalon, Inc., 702 F. Supp. 2d 514, 534, 535-36 (E.D. Pa. 2010). To avoid misunderstanding, the issue for pre-MMA drugs is not that no later filer can ever enter the market. It is that later filers are delayed even beyond the point where they win a patent suit. See, e.g., Hemphill, Paying for Delay, supra note 61, at 1587; Hemphill, Aggregate Approach, supra note 60.

${ }^{159}$ Indeed, in earlier work one of us assumed that this would be the case, asserting that the bottleneck does not arise in the post-MMA regime. See Hemphill, Paying for Delay, supra note 661, at 1587; cf. Hemphill, Aggregate Approach, supra note 60, at 660-61 (assembling evidence that the post-MMA regime turns out to contain a similar bottleneck). Whether the assertion proves correct depends on whether our proposal is accepted. 
